\title{
Financial Deregulation Bounding to Credit Mobilization in Nigeria: A Case for the Real Sectors and SMEs
}

\author{
Ofoegbu Donald Ikenna \\ (Department of Economics, University of Ibadan, Nigeria)
}

\begin{abstract}
Employing time series data from 1970 to 2009, sourced from the Central Bank Statistical Records, on an Autoregressive Distributed Lag (ARDL)-Bound Test Model to test for the long and short run impact of financial deregulation and the possibility of credit crunch towards the real sector, our results interestingly reveals that deregulating the Nigerian financial system had an adverse boomerang effect on the credits allocated to the real sectors in the long run, and in the short run, financial liberalization was in all insignificant and negative. On investigating the presence of credit crunch in the long and short run, our results leads us to the conclusion that Deposit Money Banks (DMBs) in Nigeria have a strong discriminating credit behaviour towards the real sectors (Agriculture, Manufacturing) and the SMEs, as credit crunch is present in these sectors, in both the short and long run indicative by the inverse relationship between increasing deposit liabilities that makes up savings and the credit that flows to these sectors. Suggesting that credit crunch does exist in Nigeria, when the focus is narrowed down to vital sectorial level that can save the economy and not shallow aggregates that deceives us, to thing all is well.
\end{abstract}

Key Word: Financial Liberalization, Credit to Private Sector Components, ARDL-Bound Test, Credit Crunch

\section{Introduction}

Recent reports by the Central Bank of Nigeria (CBN) annual report (2011) suggest that the contribution of the non-oil sector to the Gross Domestic Product (GDP) growth have been encouraging. Pleasing as the news may be, a questioning of the significance of this growth when a reflection of what could have been of the sector and the magnitude of positivism in its multiplier effect on the economy if well attended, makes current government attempts a child's play. Yesteryears saw the dominance of the agricultural sector in the contribution of not only domestic GDP but bragging pride in the natural endowment of the country, especially in its rich agricultural produce- the famous groundnut pyramids in the North, cocoa and coffee pyramids in the South, one of the World's 5 Top Most Producers of Palm Produce, Cassava, Yam, Cocoa, Basic Fruits, Groundnut/Peanut, Sesame, Sorghum, Rubber, Cotton, Gum Arabic and Hides and Skins, etc. However, both trends and tables have turned to disgraceful and unrealistic edge; evidence in heightened unemployment, unfavourable balance of payment, high prices and inflation, deeper and wider hunger poverty spread, food shortage and ironically, food wastage. These are the surfacing consequences obtainable in the derailment of key real sectors (Agriculture and Manufacturing) responsible for food production, raw material production and processing. A good number of studies (Ewegbemi, 2007; Efobi and Osabuohien, 2011) have reported factors like; oil boom, low income level, poor infrastructure, distortions in exchange rates, non-government commitment, rural-urban migration rate, nonmechanised techniques, unattractive nature of agriculture, geological factors, government type, etc to be key mitigating factors. True as these factors may be, the generality lies in two simple truths- first, "...Money Answereth All Things" and secondly,“...The Love Of Money Is The Root Of All Kinds Of Evil Which Some Converted After, Erred From The Fate And Pieced Themselves (And All Concerned) Through With Many Sorrow". The former suggest the need for ample mobilization of fund (Money) into All aspect of real sector activities (i.e. agricultural funding from land/animal/crop purchase, tilling, planting, breeding, harvesting, sorting, processing- via improves value chain, storage and delivery) to attain optimality in agriculture. While the latter, is a caution against the impending doom that befalls a Nation when the Fate (of its key real sectors i.e. Agriculture and Manufacturing) is neglected in pursue of other glittering sectors (oil sector, and other non-real sector) by tooth and nail, hook or by crook. In attempt to heed this calamity, the Nigerian government, saw the need for a viable financial institution that functions to mobilize fund from idle surplus units to the investable credit deficit units and priority units. to ensure the smoothing functioning of fund mobilization and credit distribution to the key sector that are prone to credit shortages, the government's monetary regulatory agent (CBN) prior to 1986, sort, designing and implementing its financial policy to favour the improvement of these key sectors (of agriculture and manufacturing) with the aid of strict regulated direct monetary policy tool that involves the imposing interest rates ceilings, mandatory sectorial allocation of credits and quantitative ceiling in bank credits to the private sectors, which Ogwuma (1993), and Ojo (1993) reported to have engendered distortions and inefficiencies that resulted to low direct investment, inadequate fund, overvalued domestic currency and sluggish movement in monetary and credit aggregates; that the economy was found engulfed with 
a general lull. With similar recognition and complain on the directly-regulated monetary measures across economies of the world (McKinnon and Shaw 1973; Fry 1978, 1995; Mushsin and Pentecost 2001; Stulz and Mishkin 2001; Levine 2001; Emenunga 2009), Nations sort to a more liberalized market system, where price and allocation are determined by the forces of demand and supply,, package in their various Structural Adjustment Programs (SAP).

Liberalizing the financial market otherwise called financial deregulation, describes the elimination of credit controls, deregulating interest rates, erasing of entry barriers into the financial services industry, development of capital markets, increased prudential regulation and supervision, and liberalization of international capital flows. Such liberalizing reforms are expected to increase competitive efficiency within the financial market by improving allocation efficiency, for example, the elimination of regulations and price distortions allow savings to be directed to highest yielding (risk-adjusted) form of investment. It leads to higher operational efficiency as increased competition reduces the cost of financial intermediation. And lastly, deregulating the reform measures generate an improved range of financial products and services adaptable to changing consumer needs. Stulz (1999) and Mishkin (2001) assert that financial deregulation promotes transparency and accountability, reducing adverse selection and moral hazard while alleviating liquidity problems in financial markets. Enticed with these expectations, many Nations - Nigeria inclusive, have implemented Financial Deregulation as a component of the Structural Adjustment Program adopted from 1986 under varying financial structures and different macroeconomic conditions. So far, cross empirical testing's suggest ambiguility in on the effect of financial liberalization/deregulation on major economic indicators of GDP, Savings, Credit to the Private Sector, Interest Rates, etc. Some a positive effect (Fry 1978,1995; Bandiera et al 2000; Levine 2001; Bakaert et al 2004; Fowowe 2008; Okpara 2010; Rehimat et al (2010), others a negative effect (Eichengrea and Lebang 2003; Emmanuel 2006; Shahnoushi et al 2008; Okpara 2010). However the effects, considerations need be made on the measuration of the degree of financial deregulation \{most of which are partial (M2/GDP, Credit to private sector/GDP) or extremes (dummy 0 and 1, interest rate deregulation dummy) \} as poor (false/partial) measurement would only imply to poor (false/partial) results and indeed poor (false/partial) recommendations. Also, sector specific effects need be tested as many if not all studies are tested at aggregate macro variables like GDP, Savings, Aggregate Credit, etc. With these at the back of our minds, and the news of improving non-oil sectors (CBN, 2011), with the claim of No-Credit Crunch in our financial system (World Bank, 2010), this study attempts to fill the gaps by investigating the effects of financial deregulation on a bridge variable between savings and investment (economic growth) - "Credit to the Private Sector"; not just on aggregate level but key credit components of Agriculture and Manufacturing \{and possibly SMEs\}, after constructing a better measure to the degree of financial deregulation.

\section{Background: Agriculture And Manufacturing In Nigeria}

An indebt description of the nature of agriculture in Nigeria, is better achieved when viewed under the scope of selected crop performance overtime; considering agricultural activity of major crops; their production level, volume of export, imports, and aggregate funding and performance relative to the entire economy.

\section{Palm fruit/kernel/oil:}

positioned as the world's topmost producer as at 1960 with more than 42,000,000 metric tonnes of palm fruits, next with Congo and Brazil (with Malaysia nowhere close to the first nine, and dependent on Nigeria for palm fruit seedling), lost its positioning when the country shifted it's earning interest towards crude oil instead in 1985, falling to third topmost producer, a position it hold till date after its then seed import customer Malaysia holds the first spot. Despite falling international prices (FAO, 2011) as suppliers increased, Nigeria seem more interested in importing internationally pressed and processed palm oil and its bi-produce; as observed in its large import volume (464,100 tonnes) as against a depleting export (25,000 tonnes) which is dominated by unprocessed palm fruits; despite increasing growth potential of this vital crop that is a primary raw factory input in the production of soda, soap, spa ingredients, cosmetics, broom, raffia, and building materials, etc. 


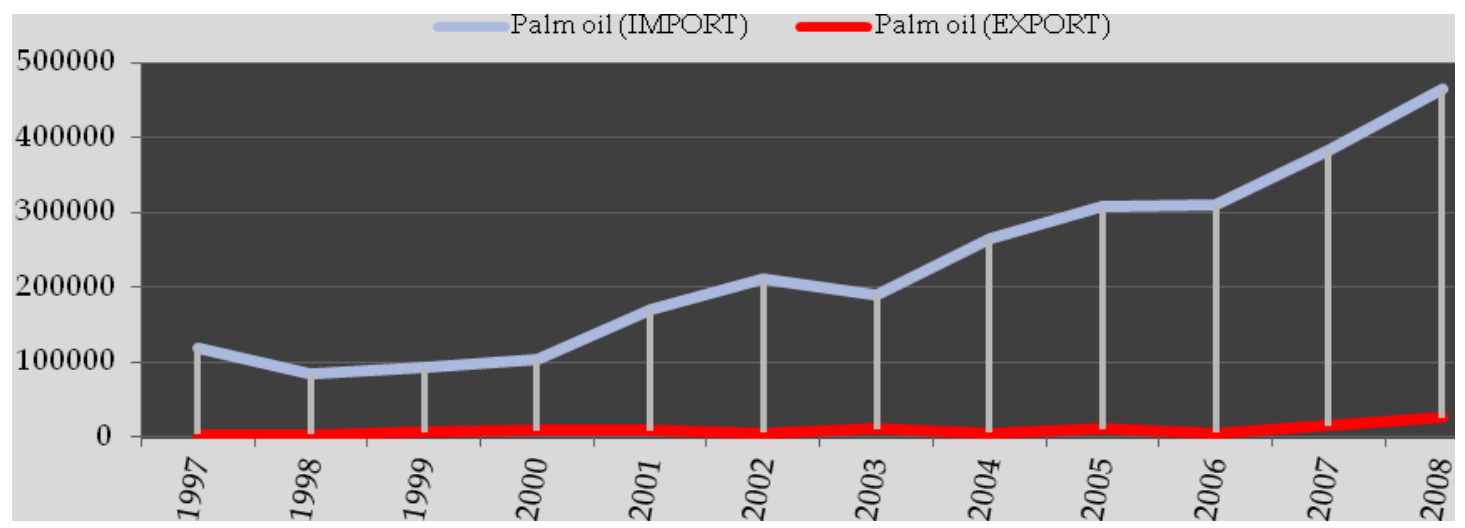

Figure 1: Spread between Import and Export of Palm Oil (tonnes) 1997-2008

Source: Authors Analysis

\section{Cocoa Beans:}

the key ingrident in coffee, chocolate, and most breverage manufacturing all over the world. Nigeria as at 1961 , produced $14 \%$ of the world cocoa beans, as its pyramids stood tall in the southern part of the country, sliding to $8 \%$ as at 2009 with strong indications of further decrease. Data from the FAO (2011) suggest increasing international prices of cocoa beans that can translate to increased foreign earnings if possibilities of increase production can be catapulted outside the countries boarder, without offsetting imports of canned biproducts than ought to be process within the boarders. With a teeming population favouring imported products, not really as a result of deficient domestic supply and processiong by infant home firms sabotaged by government negligence, epilectic infrastructures, and unfavourable competitions from unchecked foreign counterparts welcomed by a porrious trade boarders, Nigeria's import volume of cocoa bi-produce have been on the increasing side, with decreasing raw cocoa seed produce- loosing our position as the second largest producer of cocoa after Ghana in 1963, pursed by Brazil and Cote'd Ivoire (former Ivory Coast) in third and fourth position in 1963 \{Ghana 400,000mt and Nigeria 210,000mt . By 1995, Cote'd Ivoire claims the world's largest producer of cocoa with 1,200,000mt and Nigeria sliding downward fifth with a low average harvet producce less than 20,000 tonnes. The trend has not been too different from today.

\section{Cassava and Yam:}

Nigeria constantly retains both absolute and comparative advantage in the production of cassava through-out the world, accounting for $19 \%$ of world production next to Thailand and Brazil (FAO, 2011), Cassava is the chief source of Tapioca, Garri, and in South America a sauce and an intoxicating beverage are prepared from its juice. The root in powder form is used to prepare "farinha", a meal used to make thin cakes sometimes called cassava bread. The starch of cassava yields a product called Brazilian arrowroot and a primary ingredient in fabric/laundry firms for the production of cloth stiffening. In Florida, where sweet cassava is grown, the roots are eaten as food, fed to stock, or used in the manufacture of starch and glucose. Improving technology had revealed and proven the potentials of cassava in producing Ethanol fuel source (also used for alcohol and beverage production), and ethane an alternative clean energy. In the absence of organised large scale production, and processing mills, standing production drew close to 40,000,000mt in 2009 tending towards a decline, Nigeria's export of cassava flour $(2551 \mathrm{mt})$ has been relatively impressive, with a non-do-without import of processed cassava starch (202mt) \{ obviously at higher import price given the cost of processing for extended value chain and transportation. A very similar situation is obtainable in its (Nigeria's) yam production; decreasing product yield, reduced fraction to world contribution 40\% (1960s) to below 37\% (in 2009), and lack of foresight for added value to primary produce domestically.

\section{Fruits, Maize, Soya Beans, Karite(Shea nut),Tomatoes, Groundnut:}

The worst case of agricultural ignoramus is obtainable when the focus is shifted to Nigeria's fruit production (citrus, mango, guava, papaya, pineapple, Sugar Cane and others). Over the years, the country have enjoyed bountiful harvest of major fruits and vegetable, evidence by large volume of fresh fruit exports (at an average of 97.25 tonnes), and after harvest heaps of wastage scattered across harvest and market places (emphasising a bountiful harvest with no storage preservative technology) against an escalating import of foreign squeezed and canned/packaged fruit juice of 1030 tonnes. The current pattern is to; cheaply export sugar cane stems/stalks and import costly foreign squeezed and processed sugar, export soya bean seed and import soya bean oil, soya bean sauce, and even soya bean cake (and watch our domestic soya bean production decline, as we lose our fraction from $32 \%$ in 1997 to $25 \%$ by 2009 in Africa alone). Export relatively large volumes of 
groundnut/peanut and Karite (sheanut) seeds, to import groundnut oil for cooking, groundnut cake, shells, Sheabutter and oil based cosmetic, etc. Export fresh tomatoes and import sachet-tinned tomatoes pastry; even when domestic production is relatively stable and increasing, not forgetting the favourable international prices, and our positions as global market producers of these crops (top 10 countries). FAO (2011).

\section{Rice, Hides and Skin, Gum Arabic, Livestock:}

without the confidence of being amongst the topmost producers of rice, Nigeria in Africa has the yielded capacity of feeding a good fraction of the continent. Producing $12 \%$ of rice in African and $25 \%$ in West Africa, the tendency to improve in the finishing of its rice production to attract firstly domestic patronage before close neighbours, is threatened by escalating dependent on imported rice paddy to the tone of 701 tonnes annually (excluding 570 tonnes of rice flour) as at 2009. In the world of leather production, Nigeria's production have been rising, but not export, as we still depend on import of leader products both finished and semi finished products. Despite our rise in position of world producer of gum Arabic (22\% in 2009, from 21\% in 2004 against the world), our export is still on the down side. Limiting livestock to poultry production, increasing chicken production (184,500/1000 per head), we produce 19\% of hen egg in Africa in 2009 against $16 \%$ in 1961. Consequently, export has not been possible as domestic production is insufficient causing a need to import and smuggle into the country.

The tradition of exporting raw agric-harvest produce, only to import its processed bi-products at higher international prices not only exert pressure on domestic currency \{losing naira value relative to international currencies\}, but expands the trade-off of gainful employment that would have reduced unemployment if domestic processing industries were operational and encouraged. Furthermore, additional foreign exchange could be earned by expanding the value-chain of these crops, then exporting the agricultural bi-products at least to Africa, if not the World. These would however depend on the volume of agricultural yield, induced by the level of financing, considering the fact that most farmers are credit constrained.

Adegeye and Ditto (1985), indicated that agricultural credit can be used to enhance productivity and also to promote standard of living thereby breaking the vicious cycle of poverty in a developing economy like that of Nigeria.

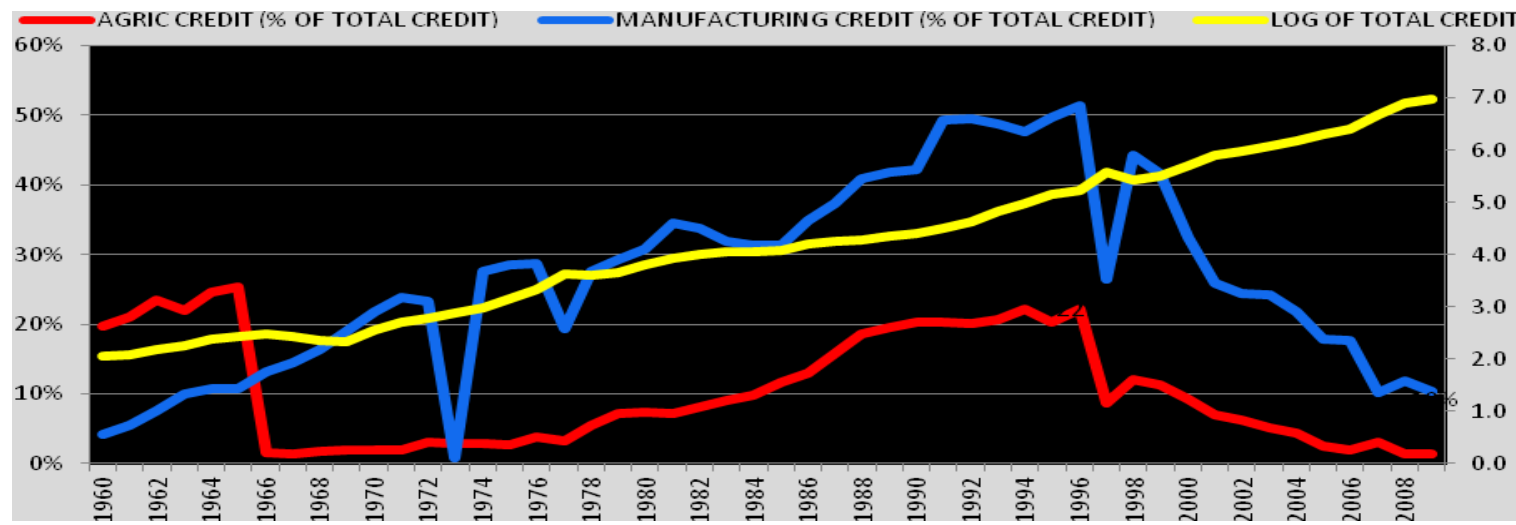

Figure 2. Ratio of Commercial Bank Credit to Agriculture and Manufacturing 1960-2008

Source: Authors Analysis

True as this is may be, Fig. 2 above does not indicate the knowledge or urgency in the need to encouraging credit flow to the agricultural sector as growth in the total credit have not been evident in the proportion of credit channelled to the agricultural sector, especially after 1996 and afterward; \{Exercise of interest rate deregulation, Universal banking introduction in 2000, Abolition of SME credit quota in 1996, Consolidation in 2004\}.

Beside these, the process of adding to the value-chain of domestic produce depends on a well functioning manufacturing industry, to transform raw primary produce to finish and semi finished bi-product. The Manufacturing sector contributed its highest peak at 9.9\% in 1983, from $3.8 \%$ in 1960 and $4.2 \%$ GDP in 2009 , up from 3.6\% in 2008. The sector's contribution to GDP has changed little over the course of the decade. Even as industries like cement and beverages may attract domestic and foreign investment, other industries wind up or relocate to neighbouring states; between 2000 and 2010, more than 850 manufacturing companies either shut down or temporarily close down production. Corporate Nigeria (2010/2011). Capacity utilisation in manufacturing is around 53\%, with an exponential downward forecast. Imports of manufactured goods sabotage sales of home grown products - manufactured goods have constituted the biggest category of imports since the 1960s. 


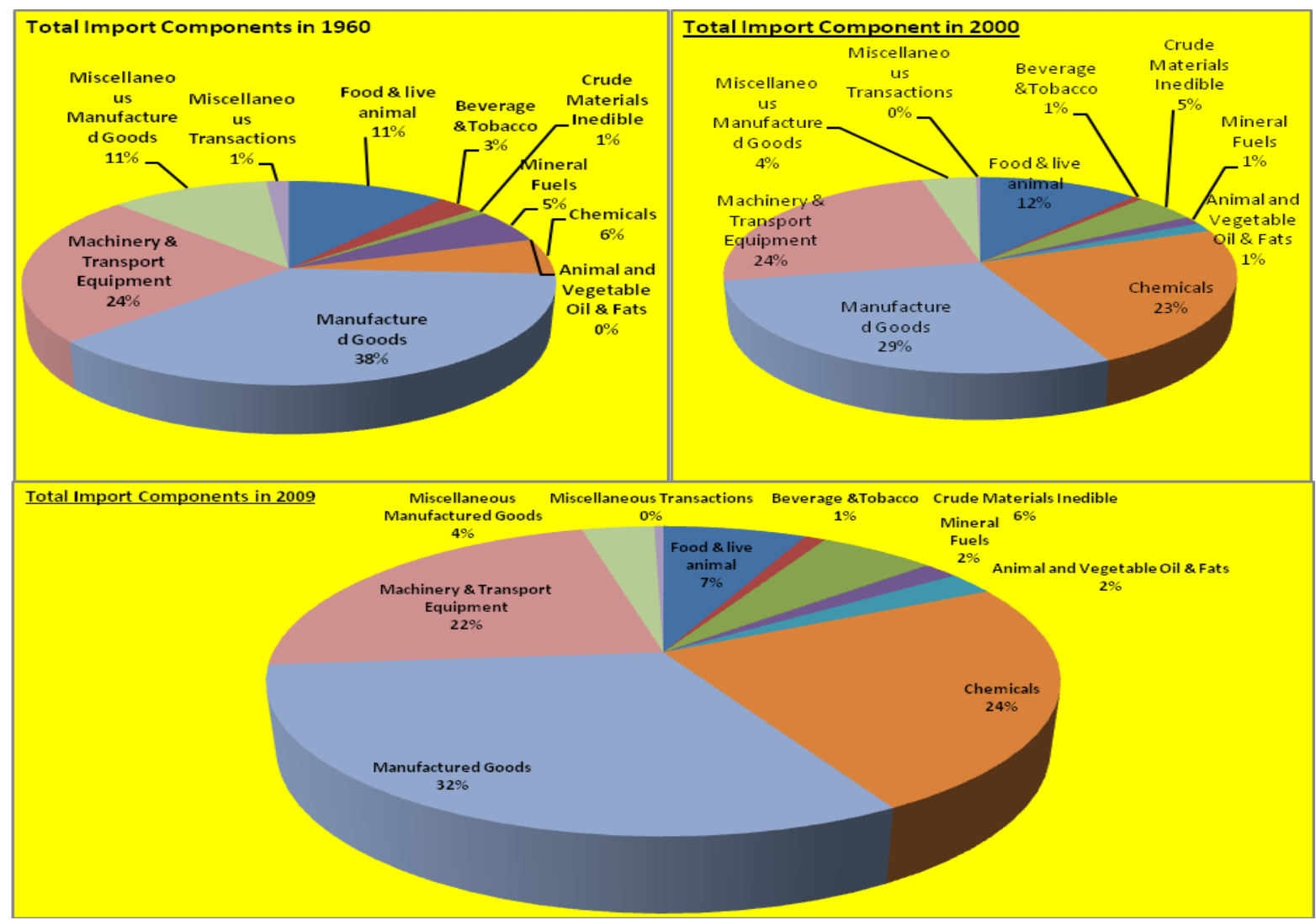

Figures 3: Fractions of Import 1960, 2000 and 2009.

Source: Author's Analysis.

The biggest problem facing manufacturers over the past decade has been poor financing, inadequate infrastructure in general and lack of power supply in particular. The country set a target of generating 6 $6^{\prime} 000$ MW of electricity by the end of 2009 , but estimated national demand is $25^{\prime} 000 \mathrm{MW}$. Manufacturers have mainly installed their own power generators to compensate for spotty supply from the state - the manufacturing industry as a whole generates around $72 \%$ of its own energy needs. Corporate Nigeria, (2010/2011). Operating private power plants/generators greatly increases the cost of manufacturing goods, which are passed down to the consumer in form of higher prices, making it difficult for Nigerian goods to compete with cheaper importsdigging poverty even deeper.

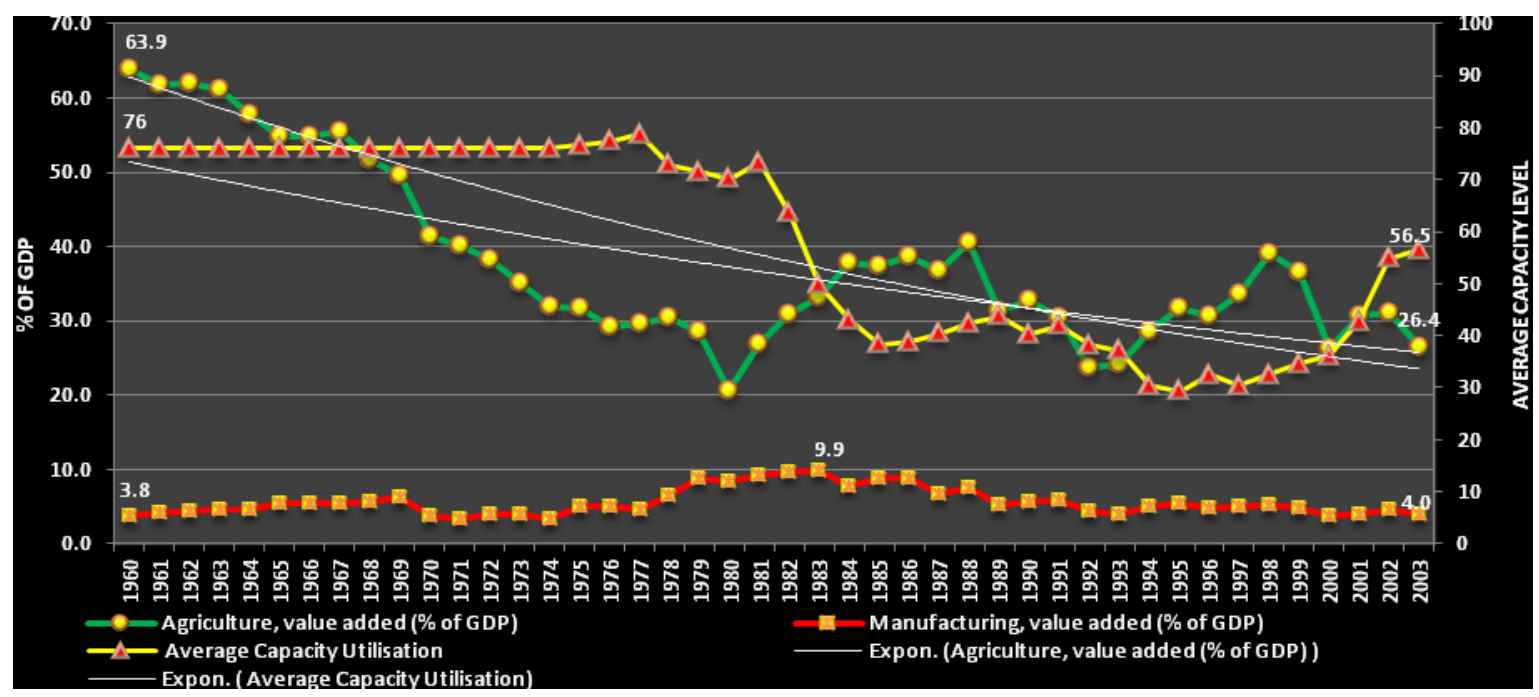

Figure 4: Agricultural and Manufacturing Value added (\%s of GDP) and Average Capacity Utilization

Source: Authors Analysis 1960-2003 
With the persistent decline in the number of larger manufacturing firms, in a low per-capita credit constrain economy, the resolving idea became the emergence of Small manageable enterprises (SMEs -Small and Medium Scale Enterprises), with relatively lower capital base and required managerial abilities. By 1992, the federal government embark on SMEs promotion campaign with credit quota for SMEs and guarantee schemes. However, trends in Fig 5 below, suggest how well that went.

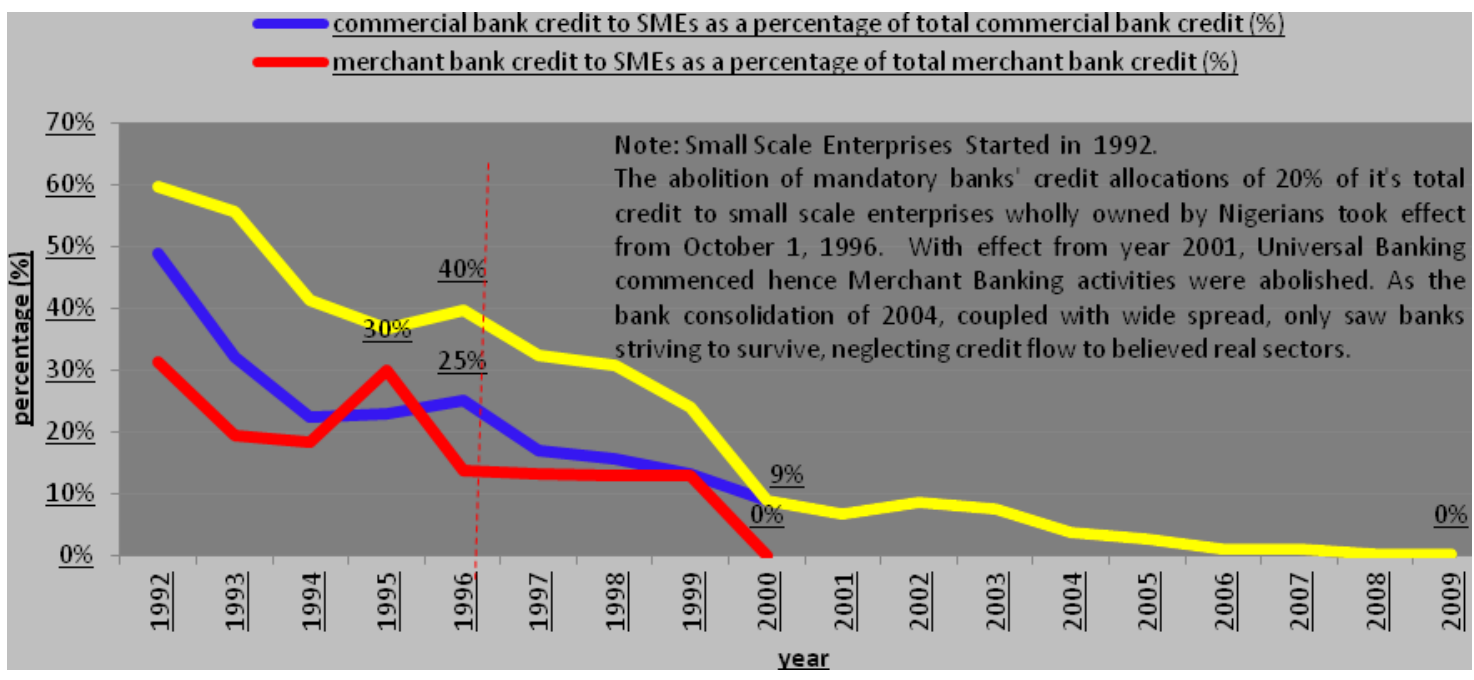

Source: Authors Analysis

Figure 5:

SMEs have contributed to the Nigerian Economy in some ways; according to NIPC (2002), represent about 90 percent of the industrial sector in terms of number of enterprises and ironically contribute a minute 1 percent of Gross Domestic Product. This is insignificant when compared to countries like Indonesia, India and Thailand, where SMEs contribute almost 40 percent of their GDP (NIPC, 2002). In many other countries SMEs forms an important part of the business landscape, but they are faced with significant challenges and obstacles that compromise their efficient ability to function and to give or contribute to the Nigerian economy. The Corporate Affairs Commission in Abuja estimates that 90 percent of all Nigerian businesses in 2001 employed less than fifty people. Similarly, a study that was conducted by the International Finance Corporation during the about the same period estimating 96 percent of all business in Nigeria are SMEs, compared to 53 percent in the USA and 65 percent in the EU. The SMEs in these two parts of the world accounts for 50 percent of their respective country's GDP. This clearly shows that given necessary support, SMEs could become an important play maker in the development processes of the Nigerian economy; it has proved to be one of the most viable sectors with economic growth potential. Another significant role of the Small and Medium Scale Enterprises in Nigeria shows can be identified in its potentials in; job creation, poverty alleviation and industrialization growth. Udechukwu, (2003) states that; the only way to revitalize, nurture and sustain small and medium scale enterprises is to complement simultaneous small and medium scale enterprises through designing, building equipment and machines through the use of local materials.

Finance is identified as the most formidable problem facing SMEs in Nigeria (Udechukwu, 2003). Ogujiuba et al, (2004)'s study revealed for 2001, that 50 per cent of the surveyed enterprises in the study received external finance while 79 per cent indicated lack of financial resources as a major constraint. As the credit flow to SMEs shrunk overtime (see figure 5 above).

\section{Literature Review:}

The benefit derivable from a healthy and developed financial system relates to savings mobilization and efficient financial intermediation roles (Gibson and Tsakalotos, 1994). True! In this light, many literatures (Gibson and Tsakalotos, 1994; Stulz and Mishkin, 2001; Loayza et al, 2002, 2003; Reinhart et al, 2005; Rahila et al, 2010 amongst plenty) indicate that banking sector development via liberalizations/deregulation are propelled by the need to deepen the financial sector and reposition for growth, to become integrated into the global financial architecture. McKinnon and Shaw (1973) were the first to suggest that liberalizing a repressed financial system led to higher interest rates which equates the demand and supply of savings. The authors claim that higher interest rates leads to increased savings and financial intermediation in improving the efficiency of 
savings and investment. The higher real interest rates increase the extent of financial intermediation that is credit allocation which in turn raises the rate of economic growth in developing countries.

In Trinidad and Tobago, Avinash And Tanisha (2010) noted that commercial bank credit plays an important role in the way in which businesses and individuals finance economic transactions. They attempted to assess the impact of commercial bank credit on economic development. Their work draws heavily from the credit channel of the monetary transmission mechanisms, which states that credit influences economic growth through its impact on capital investment. It employs a vector error correction model to firstly assess the relationship between credit and investment, and secondly to determine the casual directionality of the relationship (if any). The model found that overall, credit and growth tends to demonstrate a 'demand following' relationship. However, further analysis revealed a 'supply leading' relationship between credit and growth within key sectors of the non-oil economy.

Activating economic growth through agricultural encouragement, especially in the need added value chain, the UNIDO, CBN, BOI (2010)team- Hartwich et al (2010) void of any econometric technique, but with rich inferential and descriptive analysis, advocates for the Unleashing Agricultural Development in Nigeria through Value Chain Financing.

Examining the impact of institutional support and macroeconomic policy on the growth performance of the agricultural sector in Nigeria. Using data on relevant variables were collected from the Central Bank of Nigeria Statistical Bulletin, 1970-2008. Benson (2012), carried out a unit roots and cointegration test on data variables such as the volume of credit to the agricultural sector, interest rate spread, dummy $\{0$ and 1$\}$ for institutional reforms, and deficit financing. With variables at I(1) and established cointegration, with a Fully Modified Ordinary Least Squares, the results indicate that the volume of credit to the agricultural sector, deficit financing income (GDP) and institutional reform (Dum) were positively and significantly accounted for innovations in agricultural output for the period studied. The interest rate spread has a negative relationship with agricultural output growth but not significant. He therefore recommends liberalized interest rate policy and enhanced institutional support to the agricultural sector. Enriching as his results may be, the representation of institutional reforms described as liberalization were relatively too extreme and fails to capture the degree of institutional changes; changes in a dynamic institution - either a tightening or loosing is a matter of degree, that may not yield immediate full adjustment. Thus dummies of one and zero are like an off/on switch with no attention on degree.

Henny et al (2011) analyze the influence of banking development indicators, agriculture sector and manufacturing industry sector on economic growth in Indonesia and to examine the relationships between banking development and economic growth. A Vector Autoregressive time-series econometric model used in the study, estimating three banking indicators that are assets, credits and third party fund, economic growth average per capita at constant price 2000 and two variables of economic growth in agriculture and manufacturing industry. Two dummy variabels are also implemented in VAR model, they are monetary crisis and implementation of Arsitektur Perbankan Indonesia (API) or Indonesia Banking Architecture. Based on the two-stage data processing, the research reveals empirical evidence that banking development, agriculture sector and manufacturing industry sector affects the economic growth although the percentage of the contribution are relatively small.

Emeni and Okafor (2008) observed that one of the consequences of the consolidation reform is its effect on the lending to small businesses, divided the effects to static and dynamic effect (restructuring, direct and external) in their study, data from cross-sectional survey were put to the test using the Ordinary Least Square method. The analyses show that bank size, financial characteristics and deposit of non-merged banks are positively related to small business lending, while for merged banks the reverse is the case. From the result, it was evident that mergers and acquisitions have not only static effect on small business lending but also dynamic effect, therefore, given the central position of small businesses in the current government policy on industrialization of Nigeria, policy makers in Nigeria should consider both the static and dynamic effects of mergers and acquisitions on small business lending in their policy thrust.

Investigating on the effects of selected bank management ratios on rural lending and small business finance in Nigeria for the period 1992 to 2007, Toby (2001) used the Multiple Ordinary Least Square (OLS) estimation method to attain the set objective. He found that a critical gap exists in the Nigerian rural and SMEs sectors, his results suggested that rural bank management expanded aggregate credit in such a manner that constrained their liquidity profile, particularly from year 2007. The excess liquidity in the banking system between 1992 and 2007 did not improve the flow of credit to SMEs in Nigeria. He thus concluded that the banks have failed in their social role of financing the entrepreneur - innovator by restricting the spread of fiat money contrary to the expectations of the Keynes-Schumpeter model.

Woldie and Kolawoleadeniji (2008) examine how financial liberalization reform has improved access to external finance for Small and Medium Scale Enterprises (SMEs) in Nigeria, using new coding rule to measure the extent of financial sector liberalization in Nigeria. Using Principal Component Analysis (PCA), 
correlation among the financial liberalization components was interacted with the ratio of SMEs credit to GDP (PGDP) in order to measure the flow of credit to SMEs during the preliberalization and post-liberalization periods. The result from the PCA shows that the flow of credit to SMEs is mixed. The contributions of the first component are negative, followed by positive contributions in the next three components, thereafter showing positive and negative oscillations in the remaining components. An economic interpretation of the results vis-àvis ratio of SMEs to GDP is that the contributions of behavior of credit to the principal components have been relatively unstable.

To this ends, how did aggregate credit respond to financial deregulation? Did the sectorial credit to agriculture, manufacturing and SMEs respond in similar fashion?

\section{Data, Model And Methodological Framework}

Annual time series data (1970-2009) for Nigeria were obtained from the Central Bank of Nigeria (CBN) Annual Statistical Bulletins and the World Bank Development Indicator 2009. The economic model has been specified by the standard literature following King and Levine (1993), King Ross and Levine (1997), Levine and Zervos (1998), Levine et al. (2000) and Wachtel (2001), Shrestha, M. B. and Chowdhury, K.,(2005) specifying the demand for money and savings function subjected to testing the effects of financial developments as; $m / p_{t}=\alpha_{0+} \alpha_{1} y_{t}+\alpha_{2} s / y_{t}+\alpha_{3} i-p_{t}^{e}+\mu_{t}$

Where, $\mathrm{m} / \mathrm{p}$ is the demand for money, dependent on the level of income $\mathrm{y}$, volume of accumulated average savings $\mathrm{s} / \mathrm{y}$, the real interest rate $\mathrm{i}-\mathrm{p}^{\mathrm{e}}$ and $\mathrm{e}$ is the error term. If the case of a transitory demand for cash balance prevails in a constrained situation, we can assume further that credit demand equals the money demand. Also when the effect of financial liberalization reform is to be tested, equation one seems restrictive as it has no variable therein to really reflect the degree of liberalisation effect thus the equation is restated as;

$\mathrm{LCrdp} / \mathrm{y}_{\mathrm{t}}=\alpha_{0+} \alpha_{1} \mathrm{y}_{\mathrm{t}}+\alpha_{2} \mathrm{Ls} / \mathrm{y}_{\mathrm{t}}+\alpha_{3} \mathrm{i}-\mathrm{p}_{\mathrm{t}}^{\mathrm{e}}+\alpha_{4}$ FinLb $_{\mathrm{t}}+\mu_{\mathrm{t}}------$ (2)

Where; Crdpy is credit to the private economy/credit components as a ratio of aggregate output. $y_{t}$ is economic growth, $\mathrm{i}-\mathrm{p}^{\mathrm{e}}$ (afterward represented as RINTR) is the real interest rate, s/y is the savings output ratio and FinLb is the financial liberalisation measure. $\mu_{\mathrm{t}}$ is the error term, $\mathrm{L}$ (in front of variables) is the Logarithmatic/log indicator for growth rate (it is not included for real interest rate because of the presence of negativity, and financial liberalization index) and $\square_{0}-\square_{4}$ are the parameters coefficients. $\square_{0}, \square_{1} \ldots \square_{4}>\mathbf{0}$ $\mathrm{L}(\mathrm{Crdp} / \mathrm{GDP})=\alpha_{0}+\alpha_{1}$ LGDP $+\alpha_{2}$ LSavgdp $+\alpha_{3}$ RINTR $+\alpha_{4}$ FinLb $+\mu_{\mathrm{t}}----(3)$. $\alpha_{0}, \alpha_{1} \ldots \alpha_{4}>0$ Given the objective of the paper, equation three will be the basic equation for the study.

Most of the studies that involve financial liberalization use individual financial liberalization policies such as real interest rate, credits as a ratio of economic output proxied with gross domestic products, or the money supply as a ratio of gross output, either treated the partial financial liberalization as the full liberalization. While others measure liberalization use dummy variables of zero and one ( 0 - for pre liberalisation and $1-$ for liberalization period) to capture liberalization; this technique fails to capture the progression sequence of liberalization in the system ignoring the fact that liberalization at various point in time may differ given that liberalization is a dynamic exercise involving different aspects and in aggregate reflects varying level of degree in liberalization. To avoid paying for the penalty of losing full liberalization information, we construct an index to measure the degree of financial liberalization in aggregate. To do this we consider seven components of financial liberalization in the system and record a 0 or 1 score for each following components following observations as various reforms are implemented in the country overtime. After which, an aggregate of the scores is taken to give us a close proxy of the degree of financial liberalization. (See table in appendix).

Settling for a methodology to investigate the long run and short run relationship among the running variables, one would need to use a fitting Co-integration technique for empirical analysis. Most of the studies employ the Johansen-Juselius (1992) and Engle Granger (1987) Co-integration technique which requires that all the series should have the same order of integration. This study uses Bounds testing approach to Co-integration employed within the framework of Autoregressive Distributed Lag model (ARDL) developed by Pesaran, et al. (1997), as it can be applied without considering the same order of integration of all variables i.e. either they are integrated of order I $(0), \mathrm{I}(1)$ or of mixed order. Contrary to other single equation co-integration procedures, this technique has certain econometric advantages. First, as the Engle-Grander method experiences endogeneity problems and failure to test hypothesis on the estimated coefficient in the long-run, Autoregressive Distributed Lag (ARDL) approach avoids such problems. Secondly, short run and long run parameters of the model are estimated simultaneously. Thirdly, each and every variable is presupposed as endogenous. Fourthly, the econometric methodology does not face the dilemma of finding the order of integration among the variables and of pre-testing for unit root. Hence, Autoregressive Distributed Lag (ARDL) approach of Pesaran et al is applicable even if the underlining variables are of $\mathrm{I}(0)$, of $\mathrm{I}(1)$ or mutually co-integrated, as all other methods entail that the variables in a time series regression equation are integrated of the same order, essentially one i.e. the variables are I(1). The statistic underlining this procedure is the familiar Wald or F-statistic in a generalized Dickey-Fuller type regression, which is used to test the significance of lagged levels of the variables under 
consideration in a conditional unrestricted equilibrium Error Correction Model (ECM) (Pesaran et al, 2001). One more reason to use the ARDL approach than other co-integration technique is its extra robustness and better performance for a small sample size as in this study.

The ARDL bounds test is based on the F-statistic, which has a non-standard distribution. Two critical bounds are given by Pesaran, et al. (1997) for Co-integration test. The lower critical bound assumes that all the variables are $\mathrm{I}(0)$, while the upper bound assumes all the variables to be $\mathrm{I}(1)$.

Following Unrestricted Error Correction Model, the general form of ARDL is given as;

$$
\Delta y_{t}=\alpha_{0}+\lambda_{1} y_{t-1}+\lambda_{2} x_{t-1}+\sum_{i=1}^{k} \alpha_{1} \Delta y_{t-i}+\sum_{i=1}^{k} \alpha_{2} \Delta x_{t-i}+\mu_{t}
$$

At start, the test for null hypothesis of no Co-integration against alternative of the existence of a long run relationship is tested by using F-test such as;

$\mathrm{H}_{0}=\lambda_{1}=\lambda_{2}=\ldots \ldots .=\lambda_{\mathrm{n}}=0$

$\mathrm{H}_{1}=\lambda_{1}=\lambda_{2}=\ldots \ldots . .=\lambda_{\mathrm{n}} \neq 0$

If the computed F-statistic falls above the upper bound critical value of F-tabulated developed by Pesaran, the null of no Co-integration is rejected which implies that long run relationship exists among the variables of interest. On contrary, if it falls below the lower bound, then the null of no Co-integration cannot be rejected. Finally, if it lies between these two bounds, the result seems inconclusive.

Having confirmed the existence of a cointegrating relationship among the variables, then we determine the lag order of the variables this will be done using Akaike Information Criteria, or Schwarz Bayesian Criteria or $\mathrm{R}^{2}$. After determining the lag order, the long run coefficients of the model are estimated and then short run estimations are carried out followed by the Error Correction Model (ECM). The ECM estimation coupled with ARDL model is obtained from the ARDL equation terms of the lagged levels and the first differences of the dependent and independent variables (Pesaran, et al. 1997).

Specifying the credit equation three in an Autoregressive Distributed Lag (ARDL) form along with its testable components, have the following series of ADRL with the following interchanging credit component variables:

$\operatorname{Crdpgdp}_{\mathrm{t}}{ }_{\mathrm{Agg}} \quad=$ Aggregate Credit to the Private Sector as a ratio of current GDP

Crdpgdp ${ }_{t}{ }^{\text {Agri }}=$ Credit Loan and advances to Agriculture as a ratio of current GDP

Crdpgdp $_{t}{ }^{\text {manf }}=$ Credit Loan and Advances to manufacturing as a ration of current GDP

Crdpgdp $\mathrm{p}_{\mathrm{t}}^{\text {SMEs }}=$ Credit Loan and Advances to SMEs as a ration of current GDP

\section{Equation 1:}

$$
\begin{aligned}
& \Delta L \operatorname{Crdpgdp}^{a g g t}{ }_{t}=\alpha_{0}+\sum_{i=1}^{k_{1}} \alpha_{1} \Delta L g d p_{t-i}+\sum_{i=1}^{k_{2}} \alpha_{2} \Delta L \operatorname{Savgdp_{t-i}}+\sum_{i=1}^{k_{3}} \alpha_{1} \Delta \operatorname{Rint}_{r_{t-i}}+\sum_{i=1}^{k 4} \alpha_{1} \Delta \operatorname{Finlb}_{t-i}+\sum_{i=1}^{k_{5}} \alpha_{1} \Delta L \operatorname{Crdpgdp}^{a g g t}{ }_{t-i} \\
& +\lambda_{1} \operatorname{Lgdp}_{t-1}+\lambda_{2} \operatorname{LSavgdp}_{t-1}+\lambda_{3} \operatorname{Rint}_{t-1}+\lambda_{4} \text { Finlb }_{t-1}+\lambda_{5} \operatorname{LCrdpgdp}_{t-1}^{\text {aggt }}+\text { ECM }_{t-1}
\end{aligned}
$$

\section{Equation 2:}

$$
\begin{aligned}
& \Delta L \operatorname{Crdpgdp}^{\text {agric }}{ }_{t}=\alpha_{0}+\sum_{i=1}^{k_{1}} \alpha_{1} \Delta L g d p_{t-i}+\sum_{i=1}^{k_{2}} \alpha_{2} \Delta L \operatorname{Savgdp_{t-i}}+\sum_{i=1}^{k_{3}} \alpha_{1} \Delta R \operatorname{int} r_{t-i}+\sum_{i=1}^{k 4} \alpha_{1} \Delta \text { Finlb }_{t-i}+\sum_{i=1}^{k_{5}} \alpha_{1} \Delta L C r d p g d p^{a g r i c} \\
& +\lambda_{1} \operatorname{Lgdp}_{t-1}+\lambda_{2} \operatorname{LSavgdp}_{t-1}+\lambda_{3} \operatorname{Rint}_{t-1}+\lambda_{4} \text { Finlb }_{t-1}+\lambda_{5} \operatorname{LCrdpgdp}_{t-1}^{\text {agric }}+\text { ECM }_{t-1}
\end{aligned}
$$

\section{Equation 3:}

$$
\begin{aligned}
& \Delta L \operatorname{Crdpgdp}_{t}^{\text {Manft }}=\alpha_{0}+\sum_{i=1}^{k_{1}} \alpha_{1} \Delta L g d p_{t-i}+\sum_{i=1}^{k_{2}} \alpha_{2} \Delta L \operatorname{Savgdp_{t-i}}+\sum_{i=1}^{k_{3}} \alpha_{1} \Delta R \operatorname{Rint} r_{t-i}+\sum_{i=1}^{k 4} \alpha_{1} \Delta \operatorname{Finlb}_{t-i}+\sum_{i=1}^{k_{5}} \alpha_{1} \Delta L C r d p g d p^{\text {Manft }}{ }_{t-i} \\
& +\lambda_{1} \operatorname{Lgdp}_{t-1}+\lambda_{2} \operatorname{LSavgdp}_{t-1}+\lambda_{3} \operatorname{Rint}_{t-1}+\lambda_{4} \text { Finlb }_{t-1}+\lambda_{5} \operatorname{LCrdpgdp}_{t-1}^{\text {Manft }}+\text { ECM }_{t-1}
\end{aligned}
$$

Equation 4:

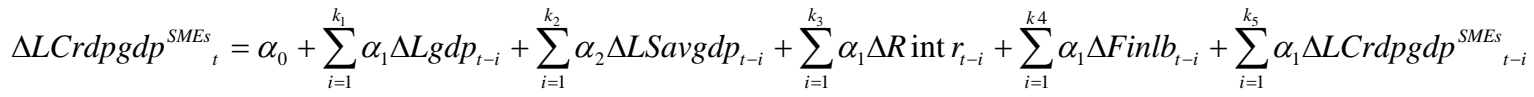

$$
\begin{aligned}
& +\lambda_{1} \operatorname{Lgdp}_{t-1}+\lambda_{2} \operatorname{LSavgdp}_{t-1}+\lambda_{3} \operatorname{Rint}_{t-1}+\lambda_{4} \text { Finlb }_{t-1}+\lambda_{5} \operatorname{LCrdpgdp}_{t-1}^{\text {SMEs }}+\text { ECM }_{t-1}
\end{aligned}
$$

In the above equations, the terms with the summation signs represent the error correction dynamics while the terms with $\lambda$ s show the long run relationship between variables. 


\section{Estimation Of Research Equations And Analysis Of Findings.}

\subsection{Unit Root Test}

While the bounds test for cointegration does not depend on the pre-testing of the order of integration, to satisfy the curiosity and quell the anxiety of spurious result from regression which is obtainable from regressing non-stationary series, and also to scrutinize the integrating level of the variables which is to ensure that the variables are not of order I(2). As put by Ouattara. B. (2004), in the presence of $\mathrm{I}(2)$ variables the computed F-statistics provided by Pesaran et al (2001) are not valid because the bounds test is based on the assumption that the variables are $\mathrm{I}(0)$ or $\mathrm{I}(1)$. Therefore, the implementation of unit root tests in the ARDL procedure is still necessary in order to ensure that none of the variables is integrated of order 2 or beyond but fall within the computed F-statistics range provided by Pesaran et al (2010). And also determining the optimal lag length of the variables based on the Schwarz Information lag length Criterion (SIC) [which is an alternative to the Akaike Information Criterion (AIC) and imposes a larger penalty for additional coefficients]; it is therefore proper for us to conduct a comprehensive standard test like the DF-GLS and Ng-Perron. For concisement, we employ the Dickey Fuller GLS (DF-GLS)

The results of the DF-GLS for stationarity testing on the data, selection of the optimal lag based on the Schwarz Information Criterion and the determined order of integration is shown in the table below:

\begin{tabular}{|c|c|c|c|c|c|c|c|c|}
\hline \multicolumn{5}{|c|}{ DF-GLS $\{$ Intercept and No Trend $\}$} & \multicolumn{4}{|c|}{ DF-GLS $\{$ Intercept and Trend $\}$} \\
\hline & \multicolumn{2}{|c|}{ At Level } & \multicolumn{2}{|c|}{ At First Difference } & \multicolumn{2}{|r|}{ At Level } & \multicolumn{2}{|c|}{ At First Difference } \\
\hline Variables & Lag & T-Statistics & Lag & T-Statistics & Lag & T-Statistics & Lag & T-Statistics \\
\hline $\mathrm{LggCrdpgdp^{Ag }}$ & 0 & 0.628132 & 0 & $-4.258540 * * *$ & 1 & -1.494015 & 0 & $-4.486770 * * *$ \\
\hline $\mathrm{I}_{\mathrm{Q} g \mathrm{Crdpgdp}}^{\mathrm{A} g i}$ & 0 & -1.206339 & 0 & $-6.125741 * * *$ & 0 & -1.251523 & 0 & $-6.667546 * * *$ \\
\hline 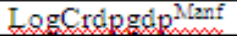 & 0 & $-1.773658 * *$ & 0 & $-6.928168 * * *$ & 0 & -2.064873 & 0 & $-7.106866 * * *$ \\
\hline 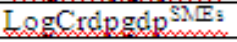 & 0 & $-2.498796 * *$ & 0 & $-8.486537 * * *$ & 0 & -2.754934 & 0 & $-8.538023 * * *$ \\
\hline LogSaygdp & 1 & -1.059173 & 0 & $-3.956053 * * *$ & 1 & -1.199463 & 0 & $-3.899653 * * *$ \\
\hline LogRgin & 0 & $2.285067 * *$ & 0 & $-5.358386 * * *$ & 0 & -1.073132 & 0 & $-5.981510 * * *$ \\
\hline RINTR & 0 & $-3.809840 * * *$ & 3 & -1.253165 & 0 & $-5.172495 * * *$ & 0 & $-7.236657 * * *$ \\
\hline FinL $b$ & 0 & -0.502907 & 0 & $-8.355731 * * *$ & 0 & -2.838236 & 1 & $-6.783784 * * *$ \\
\hline \multicolumn{5}{|c|}{ Critical Levels of Significance: } & \multicolumn{4}{|c|}{ Critical Levels of Significance: } \\
\hline $1 \%$ & & -2.625606 & $1 \%$ & -2.627238 & $1 \%$ & -3.770000 & $1 \%$ & -3.770000 \\
\hline $5 \%$ & & -1.949609 & $5 \%$ & -1.949856 & $5 \%$ & -3.190000 & $5 \%$ & -3.190000 \\
\hline $10 \%$ & & -1.611593 & $10 \%$ & -1.611469 & $10 \%$ & -2.89000 & $10 \%$ & -2.890000 \\
\hline
\end{tabular}

The result from the Dickey-Fuller Generalized Least Square (DF-GLS) shows that all the variables are stationary at difference I(1) in the present or absent of trend, as their absolute DF-GLS t-statistics values exceeds the critical values at minimum five percent. I(2) does not exist. However, at level only the real interest rate variable (RINTR), Log of Real Gross Domestic Product (LogRgdp), Log of Credit Loan Advance to the Manufacturing and Small and Medium Enterprise (LogCrdpgdp ${ }^{\text {Manf \& SMEs }}$ ) were stationary at level I(0), the remaining variable were non-stationary at level but became stationary after taking their first difference i.e. I(1) when the test was done without trend. Considering the variables given their trend at level, only the Real Interest Rate (RINTR) was integrated at level.

From the above test scenarios, it is evidence in their estimated maximum lag length is three. Thus we impose a maximum lag length of three on all the variables and then subjecting the lags to combinations that minimises the Schwarz Information criteria (SIC) and increasing R-Squared to get the optimal lag combination. This conforms to the automatic lag selected by the software analytical package.

\subsection{Cointegration Test-Bounds testing procedure:}

The DF-GLS unit root tests results indicates that we can implement ARDL models for the equations 1 to 4 using the upper bound critical values reported in Pesaran et al (2010) for determination of co-integration. The first step in the ARDL bounds testing approach is to estimate equations 1-4 by ordinary least squares (OLS) in order to test for the existence of a long-run and short run relationship among the variables by having determined the optimal lag combinations and the conducted a Wald Test (F-test) for the joint significance of the coefficients of the long run lagged one levels of the variables.

The estimates obtained from the Autoregressive Distributed Lag (ARDL)-Bound Test analysis for the equation models are shown below;

\section{Equation One:}

\section{AGGREGATE CREDIT}

Having carried out the ARDL estimation on equation one, the calculated F-statistics is computed for the joint significance of variables with $\lambda \mathrm{s}$ signs when one lag is imposed, there is a strong evidence of existence 
of co-integration among the variables. The $\mathrm{F}_{\text {Crdgdp }}{ }^{\mathrm{AGG}}$ (LCrdgdp ${ }^{\mathrm{AGG}} \mid$ LSavgdp, Lrgdp, RINTR, FinLB) $\approx 4.027$ for $\operatorname{ARDL}(1,0,0,1,1)$ is higher than the upper bound critical Value 4.01 at $5 \%$ significance level (Peseran et al, 2001: see Appendix for extract), Therefore, there exist a co-integrating long-run relationship among the variables.

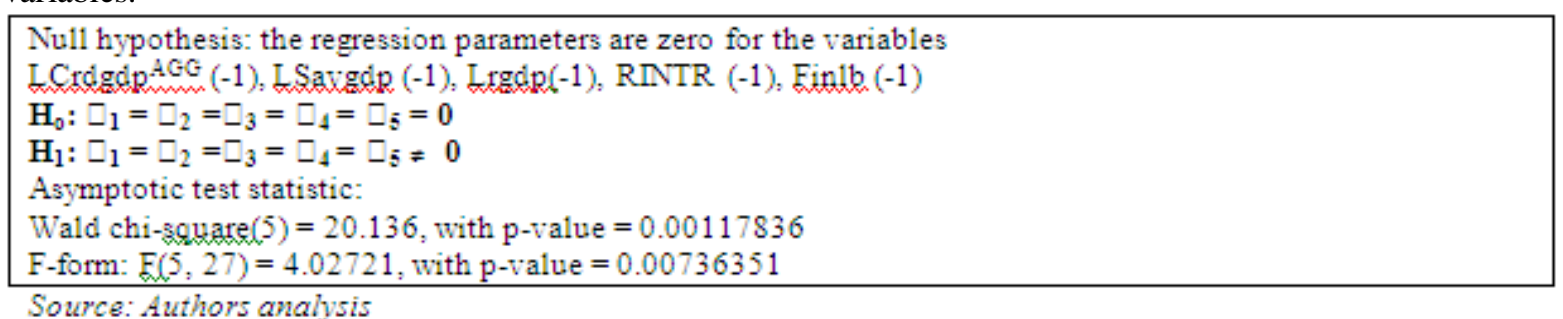

Source: Authors analysis

We therefore proceed to analyse the long and short run coefficients of the variables.

Long Run: Model 1- using observations 1970-2009 ( $\mathrm{T}=40)$

Dependent variable: LCrclpgdp $\mathrm{Ag}$

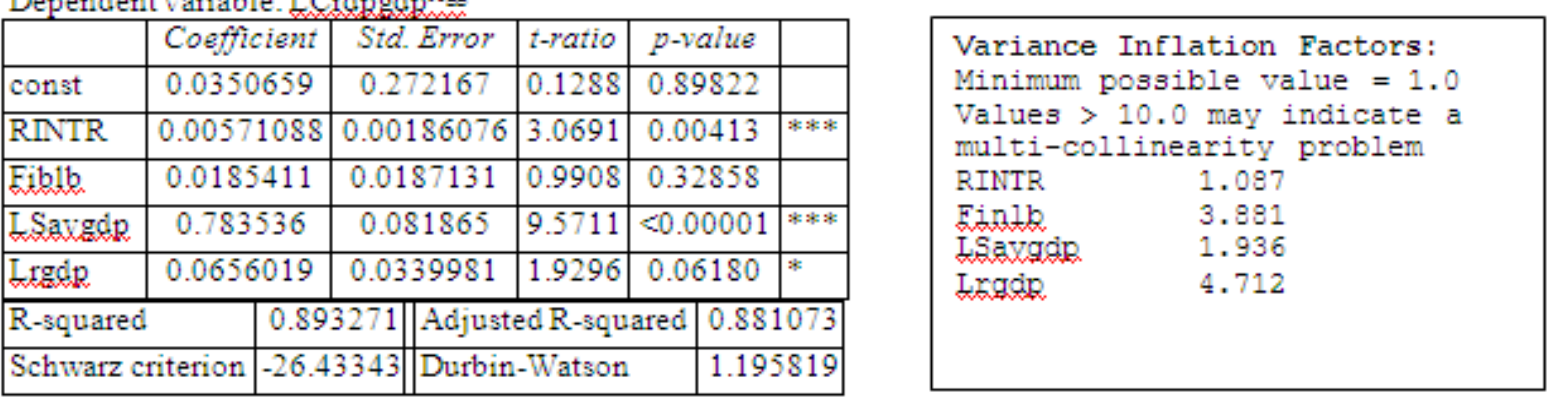

Note: $* * * * * *$ Indicates critical values; $1 \%, 5 \%$, and $10 \%$ respectively.

The long run results on the growth rate of Aggregate Credit to Private Sector as a ratio of the Gross Domestic Product (LCrdpgdp ${ }^{\mathrm{Agg}}$ ), shows that the growth rate of total financial domestic savings, real interest rate and growth in GDP do affect the aggregate credit to private sector. The coefficient of the growth rate per financial savings is positive $(\approx 0.783536)$ and highly significant at 1 percent. That is a 1 percent change in the financial savings per GDP leads to a $0.78 \%$ increase in the volume of financial credit to private sector per GDP. This is in conformity with the apriori expectation of a positive relationship, and conforming to the absence of credit crunch in Nigerian financial system the long run at aggregate, as reported by the World Bank News Report (2010), following the global financial meltdown/crises of 2007/08 and domestic banking crises 2009/10. The coefficients of real interest rate (RINTR) and growth rate of Gross Domestic Product (LRGDP) were also significant at $1 \%$ and $10 \%$ respectively. However, their values where very small and indicates a positive effects (0.00571088 and 0.0656019 respectively) on the aggregate credit to private sector. The appropriateness of the explanatory variable is backed by the goodness of fit $\mathrm{R}^{2}$ and the Adjusted $\mathrm{R}^{2}$. The curiosity aroused by the DW value is settled on the fact that if there are lagged dependent variables on the right-hand side of the regression or its parent's source, the DW test is no longer valid. (Johnson and DiNardo 1997)

The Schwarz criterion is minimal at -26.43343 , where the value of the goodness of fit of explanatory variable to the explained, stands at $89.3 \%$, supported by the R-squared adjusted. This implies that 89.3 percent variation in the growth of aggregate credit to the private sector in the long run, can be attributed to the variables of; real gross domestic output (Lrgdp), which encourages larger financial savings (LSavgdp) in response to the Real interest rate (RINTR) and financial liberalization (Finlb). The remaining 10.7\% variation in the dependent variable is accounted for by other factors embedded in the error term.

If total financial savings increases by a unit change, the aggregate credit to private sector increases by approximately 0.784 percent. Same also, a unit change increase in GDP, translates to aggregate credit to private sector growth by 0.0656 percent. The real interest rate in the model suggests a positive relationship to the aggregate credit to the private sector in the long-run, suggesting that despite discouraging real interest rate, the aggregate credit seem not to be deterred by its negativity, as access to more accessible, reliable and quick sources of credit outside credit the commercial banks seem gather rigorous, cost, or limited. The coefficient of financial liberalization- though positive, it is not significant. This lead us to the conclusion that despite the advantages of financial liberalization, its benefits is yet to bring about significant positive increases or changes in the volume of credit to the private sector. Inferring upon this, we deduce that the continued liberalization of the financial system though indicating a positive long run impact on financial widening (or financial deepening as the case may be), its manifestation on deriving benefit is yet to be accomplished.

ARDL $(1,0,0,1,1)$ Model ECM-Short Run Result for Model 1. 
Using observations 1972-2009 (T=38)

Dependent variable: $\triangle I$ CrdpgdpAgg.

\begin{tabular}{|c|c|c|c|c|c|}
\hline & Coefficient & Std. Error & t-ratio & $p$-value & \\
\hline Const & 0.0123425 & 0.0230213 & 0.5361 & 0.59595 & \\
\hline$\Delta$ LCrdpgdp $_{t-1}$ & 0.204697 & 0.117687 & 1.7393 & 0.09258 & * \\
\hline$\Delta \mathrm{Irgclpt}$ & 0.0117796 & 0.0580816 & 0.2028 & 070 & \\
\hline$\Delta \mathrm{L}$ Saygdpt & 0.76 & 0.110317 & 6.8959 & $<0.00001$ & *** \\
\hline$\Delta$ RNTR $_{t}$ & 0.0054 & 0.00157966 & 3.4299 & 0.00183 & **: \\
\hline$\Delta$ RNTR $_{\mathrm{t}-1}$ & $-7.51669 \mathrm{e}-05$ & 0.00164577 & -0.0457 & 0.96388 & \\
\hline$\Delta$ Finll & 0.0053112 & 0.0301619 & 0.1761 & 0.86145 & \\
\hline$\Delta$ Finlb $_{t-1}$ & -0.0694576 & 0.027686 & -2.5088 & 0.01796 & *** \\
\hline $\mathrm{ECM}_{\mathrm{t}-1}$ & -0.605576 & 0.152861 & -3.9616 & 0.00044 & 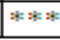 \\
\hline
\end{tabular}

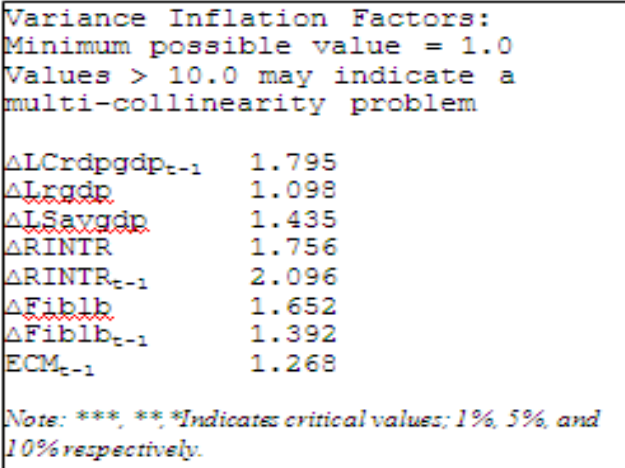

\begin{tabular}{|c|c||c|c|}
\hline R-squared & 0.779194 & Adjusted R-squared & 0.718281 \\
\hline Schwarz criterion & -32.45371 & Durbin's h & -0.006830 \\
\hline
\end{tabular}

The Error Correction Model or the Short Run Dynamics of the ARDL (as sometimes called), as shown in the table above, demonstrates that the lagged error correction term $\left(\mathrm{ECM}_{\mathrm{t}-1}\right)$ is negative and highly significant at 1 percent. Its coefficient -0.605576 implies a fairly speed of adjustment to equilibrium after a shock. Approximately $60.6 \%$ of disequilibria from previous period shocks are adjusted into long run equilibrium in the current period. The significant negative coefficient of the $\mathrm{ECM}_{\mathrm{t}-1}$, further buttress the existence of long run relationship among the variables. The result of the short run shows that the change in the total financial savings $\left(\Delta\right.$ LSavgd $\left._{t}\right)$ has a significantly high positive effect on aggregate credit to the private sector in the short run. The coefficient of changes in total financial savings of 0.760737 implies that given one shot increase in the total financial savings ceteris paribus brings about approximately 0.76 percent increase in credit to private sector in the short run. Again no credit crunch. Similar effect is observed on the changes in aggregate credit to private sector when the change emerges from the real interest rate $\left(\Delta \mathrm{RINTR}_{\mathrm{t}}\right)$. Highly significant also at 1 percent, its effect on the aggregate credit to private sector in the short run is minimally positive $(0.0054 \%)$. Other things constant, previous financial liberalization policies (lagged one $=\Delta$ Finlb $_{t-1}$ ) unlike the long run (reported in long run table above), seem to have a minor negative effect, (significant at 5 percent) on the changes in aggregate credit to private sector in the short run. Its value -0.0694576 empirically reveals that a 1 percent increase in the financial liberalization index $\left(\Delta \mathrm{Finlb}_{\mathrm{t}-1}\right)$ leads to approximately 0.8522 (i.e. $\left.10^{-0.0694576}\right)$ percentage decrease in $\Delta \mathrm{LCrdpgdp}_{\mathrm{t}}$. This switch in effects, from an insignificantly positive long run to a significant negative effect when the effect of immediate past liberalization is considered, is attributable to the manner of inconsistency in the implementation of liberalization policy reforms, as the short run is not long enough to accommodate the adjustment in the industry induced by frequent changes in reforms that normally a single reform, require a long enough periods to accomplish positive benefits. Then also is the undeveloped nature of financial institutions and functioning of financial mobilization and allocation, given the reform environment. (Nzotta and Okereke, 2009). Previous aggregated Credit to Private Sector $\left(\Delta \mathrm{LCrdpgdp}_{\mathrm{t}-1}\right)$ also had a positive impact on the current aggregate credit to private sector $(\Delta \mathrm{LCrdpgdp})$ in the short run by approximately $0.20 \%$, significant only at 10 percent.

The reliability and explanatory power of the short-run dynamic estimate is depict by its goodness of fit $\mathrm{R}^{2}$ at $77.92 \%$, further supported by a high adjusted $\mathrm{R}^{2}$ of 0.718281 . This implies that the explanatory variables in the short-run model account for approximately $78 \%$ variation in the change of the dependent variable, while the remaining $22 \%$ is accounted by variables not explicitly included in the model but comprised in the random or error term.

According to Pesaran and Shin (1999), the stability of the estimated coefficient of the error correction model should also be geographically investigated. A graphical representation of the Cummulative Sum (CUSUM) and the Cummulative Sum of Square (CUSUMSQ) of the Recursive Residual is shown below to indicate stability in the coefficient over the sample periods:

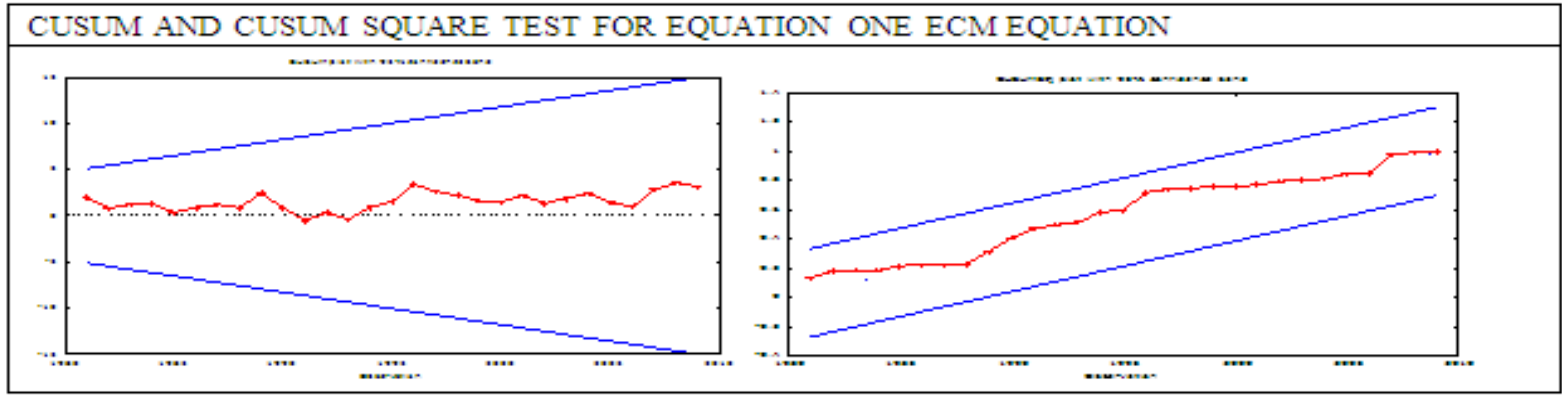




\section{Equation Two: CREDIT TO ARGICULTURAL SECTOR}

The F-statistics for $\mathrm{F}_{\text {Crdgdp }}$ Agri $\left(\right.$ LCrdgdp ${ }^{\text {Agri }} \mid$ LSavgdp, Lrgdp, RINTR, FinLB) given the optimal lag length combination where the SIC is at minimal was 1.43806 , with the optmal combination $(2,1,2,0,3)$ is lower than the lower bound value $2.45,2.86$ and 5.06 at $10 \%, 5 \%$ and $1 \%$ significance levels respectively. (Peseran et al, 2001: see Appendix for extract), this suggest that there is no long run relationship among the variables, there exist a co-integrating long-run relationship among the variables. However, the ARDL-bound testing as previously noted regresses both the short run and long run. However, the short run impact cannot be arrived at without checking for the residual in the long run. Thus there is a need to investigate for the residual in the long run given the presence of information to gain first had information on the short run estimated parameters and further verify if indeed co-integration did exist given the magnitude, sign and whether or not it is significant (as a negative and significant ecm suggest the presence of a long run co-integrated relationship).

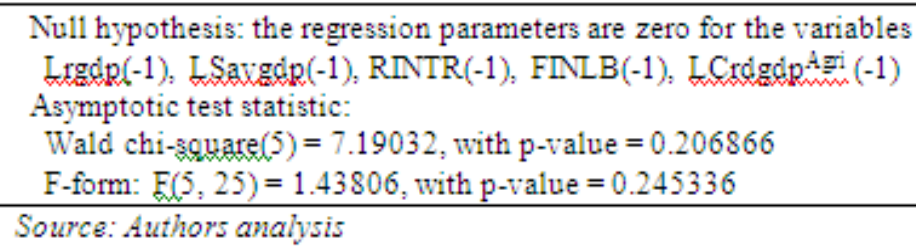

We therefore proceed to analyse the long and short run coefficients of the variables.

Long Run:

Model 2: OLS, using observations 1970-2009 $(\mathrm{T}=40)$

Dependent variable: CREDAGRI

\begin{tabular}{|l|c|c|c|c|c|}
\hline & Coefficient & Std. Error & t-ratio & $p$-value & \\
\hline Const & -2.91173 & 0.483713 & -6.0195 & $<0.00001$ & $* * *$ \\
\hline Lrgdp & 0.503488 & 0.13913 & 3.6188 & 0.00093 & $* * *$ \\
\hline ISaxgdp & 0.39877 & 0.335015 & 1.1903 & 0.24194 & \\
\hline RNTR & -0.00194791 & 0.00330705 & -0.5890 & 0.55963 & \\
\hline FINLB & -0.0675056 & 0.033258 & -2.0298 & 0.05004 & $*$ \\
\hline
\end{tabular}

Variance Inflation Factors Minimum possible value $=$ 1.0

Values $>10.0$ may indicate a collinearity problem Lrgdp $\quad 4.712$ LSavgdp 1.936 RINTR 1.087

\begin{tabular}{|l|r||l|r|}
\hline R-squared & 0.543849 & Adjusted R-squared & 0.491717 \\
\hline F $(4,35)$ & 10.43223 & P-value(F) & 0.000011 \\
\hline Log-likelihood & -0.564010 & Alvaike criterion & 11.12802 \\
\hline Schwarz criterion & 19.57242 & Hannan-Quinn & 14.18125 \\
\hline Rho & 0.781523 & Durbin-Watson & 1.462137 \\
\hline
\end{tabular}

The long run results on the growth rate of credit to the agricultural sector, like in the manufacturing suggest that only the growth in real gross domestic product had a positive effect on the agricultural sector credit growth which was significant at 1 percent; a unit increase in economic growth ceteris paribus, induces a fair below average growth in credit to the agricultural sector that comprises crop production, fishery, live stock and forestry by only $0.50 \%$ in the steady long run. The total financial domestic savings composed majorly of the total deposit liability in the commercial Deposit Money Banks (DMBs) indicated a positive effect but insignificant effect. Thus leading to the conclusion, that increasing savings in DMBs had no significant contributing impact on the credit loans and advances to this real sector of agriculture. Hence, a discriminating credit behaviour towards the agricultural sector by the DMBs is observed. The resulting effect from liberalizing reforms to increase completion therein the intermediary function of commercial banks, boomeranged as its parameter as indicates a negative effect $(-0.0675052)$, significant at10 percent; the degree of financial liberalization had not yielded any positive effect on the credit to the agricultural sector. Also, the real interest rate was also insignificant and negative. The R-squared (0.54) suggest that 54\%variation in the dependent variable can be explained by the listed explanatory variables. Since the Durbin-Watson value exceeds the $\mathrm{R}$ squared value, we follow the rule of thumb to conclude that the result is not spurious. Granger and Newbold (1974), Gujarati D. (1999).

ARDL (2, 1, 2, 0, 3) Model ECM-Short Run Result for Model 2.

Model 2:OLS, using observations 1974-2009 $(\mathrm{T}=36)$ 
Dependent variable: $\Delta \mathrm{LCrdgdp}{ }^{\text {Agri }}$

\begin{tabular}{|c|c|c|c|c|c|}
\hline & Coefficient & Std Error & t-ratio & p-value & \\
\hline Const & 0.011467 & 0.0322007 & 0.3561 & 0.72515 & \\
\hline$\Delta \mathrm{ICrclgdp}_{\mathrm{t}-1}{ }^{A \mathrm{~g}}$ & 0.11613 & 0.196682 & 0.5904 & 0.56091 & \\
\hline$\Delta$ LCrdgdpt $_{t-2}{ }^{\text {Agri }}$ & -0.188443 & 0.194815 & -0.9673 & 0.34391 & \\
\hline$\Delta \mathrm{Irgdp}$ & -0.0148076 & 0.152862 & -0.0969 & 0.92371 & \\
\hline$\Delta \mathrm{Lrgclp}_{\mathrm{t}-\mathrm{I}}$ & 0.0110487 & 0.156472 & 0.0706 & 0.94434 & \\
\hline$\Delta$ ISaygdn: & 0.0280612 & 0.403602 & 0.0695 & 0.94520 & \\
\hline$\Delta$ ISAygdn t-1 & 0.170376 & 0.372529 & 0.4573 & 0.65190 & \\
\hline$\Delta$ ISavgdp t-2 & 0.61612 & 0.354352 & 1.7387 & 0.09606 & * \\
\hline$\Delta$ RNTR $_{t}$ & 0.0035229 & 0.0019408 & 1.8152 & 0.08315 & \\
\hline$\Delta$ FINLB $_{t}$ & -0.0109771 & 0.0311902 & -0.3519 & 0.72823 & \\
\hline$\Delta$ FINLB $_{t-1}$ & 0.0146049 & 0.0350559 & 0.4166 & 0.68099 & \\
\hline$\Delta$ FINLB $_{t-2}$ & -0.0249959 & 0.0401074 & -0.6232 & 0.53955 & \\
\hline$\Delta$ FINLB $_{t-3}$ & -0.0278567 & 0.0395197 & -0.7049 & 0.48828 & \\
\hline $\mathrm{ECM}_{t-1}$ & -0.0630758 & 0.133567 & -0.4722 & 0.64141 & \\
\hline
\end{tabular}

\begin{tabular}{|c|c|}
\hline \multicolumn{2}{|c|}{$\begin{array}{l}\text { Variance Inflation Factors } \\
\text { Minimum possible value }=1.0 \\
\text { Values }>10.0 \text { may indicate a } \\
\text { collinearity problem }\end{array}$} \\
\hline$\Delta \mathrm{LCrcl}_{\mathrm{adp}} \mathrm{t}-1^{\mathrm{Agri}}$ & 1.524 \\
\hline$\Delta{ }_{1}$ Crdgdp t-2 ${ }^{A}$ gri & 1.535 \\
\hline$\Delta \mathrm{Irgdp}_{\mathrm{t}}$ & 1.137 \\
\hline$\Delta \operatorname{Irgdp}_{\mathrm{t}-1}$ & 1.191 \\
\hline SI Savgdp t & 2.864 \\
\hline II Saxgdp t-1 & 2.316 \\
\hline IL Saygdp t-2 & 2.032 \\
\hline$\triangle R D T R$, & 2.104 \\
\hline 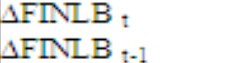 & $\begin{array}{l}1.400 \\
1.769\end{array}$ \\
\hline SFNLB $_{t-2}$ & 2.315 \\
\hline$\Delta$ FINLB $_{t-3}$ & 2.248 \\
\hline $\mathrm{ECM}_{\mathrm{t}-1}$ & 2.238 \\
\hline
\end{tabular}

\begin{tabular}{|l|r|l|r|}
\hline R-squared & 0.447157 & Adjusted R-squared & 0.120476 \\
\hline F(13,22) & 1.368790 & P-value(F) & 0.249752 \\
\hline Schwarz criterion & -11.30871 & Hannan-Quinn & -25.74031 \\
\hline Rho & -0.018219 & Durbin-Watson & 1.995893 \\
\hline
\end{tabular}

Note: $* * *, * * *$ Indicates critical values; $1 \%, 5 \%$, and $10 \%$ respectively.

The ECM for the short run further supports that no long run relationship exist among the variables as earlier put by the F-statistic having compared it with the Peseran table at $\mathrm{k}=4$ for intercept and no trend, as its coefficient is negative but not significant. The short run estimate indicates that in the short run, accumulated savings from past two years and the current real interest rate do have a positive effect on current changes in the credit to the agricultural sector. Financial liberalization was not all significant. However weak the R squared at 44.7 percent, it suggest that in the short run, major changes in the credit to the agricultural sector are on account of other factors such as other informal financial corporative groups, donations from government and other NonGovernmental Organisations, International bodies that promote agricultural produce, support from family and friend, gains from reinvestment in the agricultural business, the fact that participant in these sector are limited in terms of access to formal financial institutions to demand for credit, etc. all captured in the random error term. The stability of the recursive estimation of the model two also suggest stability in the coefficient over the sample period;

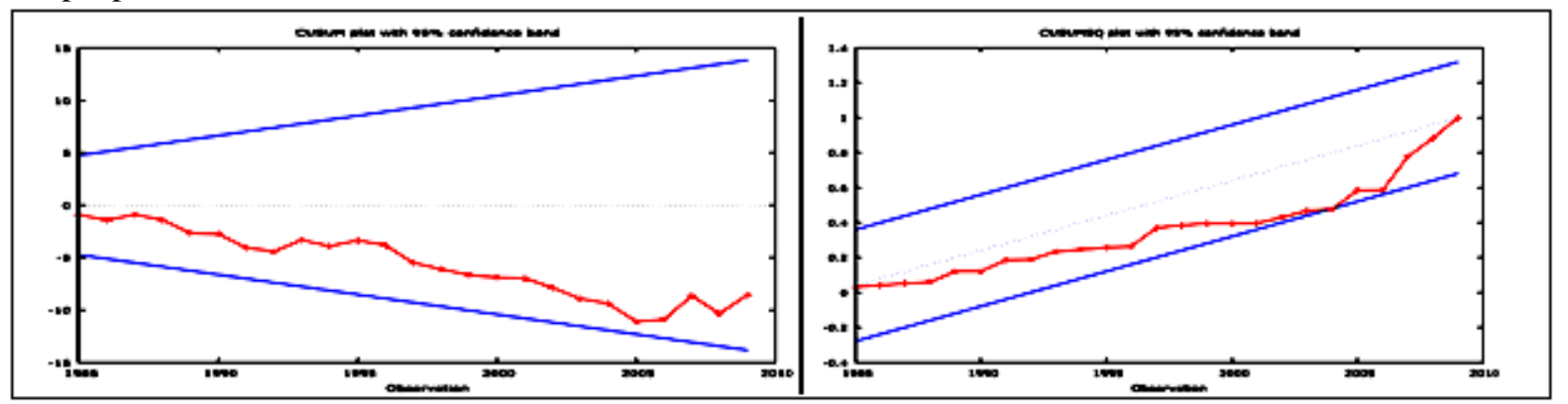

Equation Three: CREDIT TO MANUFACTURING SECTOR

On the credit to the manufacturing sector, the ARDL estimation for equation three, has a calculated Fstatistics as $\mathrm{F}_{\text {Crdgdp }}^{\text {Manf }}\left(\operatorname{LCrdgdp}^{\text {Manf }} \mid\right.$ LSavgdp, Lrgdp, RINTR, FinLB) $\approx 50.1272$ for ARDL $(3,2,0,0,1)$ is far higher than the upper bound critical Value 5.06 at 1\% significance level (Peseran et al, 2001: see Appendix for extract), Therefore, there exist a co-integrating long-run relationship among the variables.

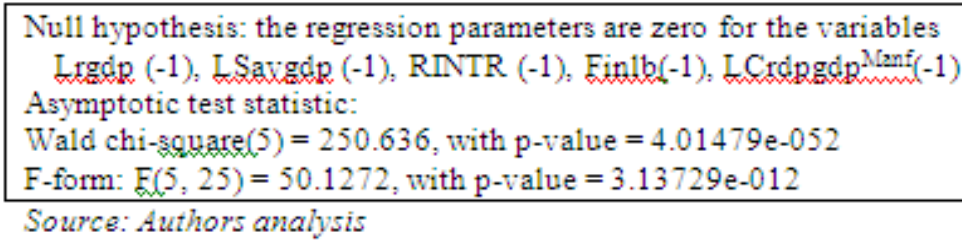


We therefore proceed to analyse the long and short run coefficients of the variables.

\section{Long Run:}

Model 3: using observations 1970-2009 $(\mathrm{T}=40)$

Dependent variable: LCrdpgdp ${ }^{\text {Manf }}$

\begin{tabular}{|l|l|l|l|l|l|}
\hline & Coefficient & Std. Error & t-ratio & p-value & \\
\hline Const & -4.15019 & 0.975841 & -4.2529 & 0.00015 & $* * *$ \\
\hline Irgdp & 0.438068 & 0.121898 & 3.5937 & 0.00099 & $* * *$ \\
\hline LSaxgdp & 0.206602 & 0.293522 & 0.7039 & 0.48617 & \\
\hline Findb & -0.156302 & 0.0670946 & -2.3296 & 0.02572 & $* * *$ \\
\hline RNTR & -0.00247794 & 0.00667165 & -0.3714 & 0.71257 & \\
\hline
\end{tabular}

Variance Inflation Factors

Minimum possible value $=1.0$

Values $>10.0$ may indicate a

collinearity problem

Lrgdp 4.712

LSaxgdp 1.936

Finllb 3.881

RNTR

1.087

\begin{tabular}{|l|l||l|l|}
\hline R-squared & 0.489044 & Adjusted R-squared & 0.430649 \\
\hline Schwarz criterion & 75.71716 & Durbin-Watson & 1.920635 \\
\hline
\end{tabular}

Note: $* * * * * *$ Indicates critical values; $1 \%, 5 \%$, and $10 \%$ respectively.

The long run results on the growth rate of Credit Loan and advances to the manufacturing sector as a ratio of the Gross Domestic Product (LCrdpgdp ${ }^{\text {Manf }}$ ), shows that only the growth in real gross domestic product had a positive effect on the manufacturing sector credits which was significant at 1 percent; a unit increase in economic growth ceteris paribus, induces a fair below average growth in credit to the manufacturing sector by $0.43 \%$ in the steady long run. The total financial domestic savings composed majorly of the total deposit liability in the commercial Deposit Money Banks (DMBs) indicated a positive effect but insignificant. We can therefore infer that increasing savings in DMBs had no significant contributing impact on the credit loans and advances to this real sector of manufacturing. Hence, a discriminating credit behaviour towards the manufacturing sector by the DMBs alas credit crunch does exist when the focal lens is pointed to the credit to the manufacturing sectors. The resulting effect from liberalizing reforms to increase completion therein the intermediary function of commercial banks, boomeranged as its parameter indicates a negative effect (0.156302 ), significant at 5 percent; the degree of financial liberalization had not yielded any positive effect on the credit to the manufacturing sector real interest rate and growth in GDP do affect the aggregate credit to private sector and the real interest rate was also insignificant and negative on account of high inflation rate and wide spread between lending and deposit rate. This forces us to conclude that liberalization encouraged the growth of the manufacturing sector through credit. The rule of thumb advocates that spuriousity of regression is first noted when R-squared value is greater than the DW value. Granger and Newbold (1974), Gujarati D. (1999). Hence the result is not spurious, despite the poor goodness of fit at approximately 49 per cent.

ARDL $(3,2,0,0,1)$ Model ECM-Short Run Result for Model 3.

Using observations 1974-2009 $(\mathrm{T}=36)$

Dependent variable: $\Delta$ LCrdpgdp ${ }^{\text {Manf }}$

\begin{tabular}{|c|c|c|c|c|c|}
\hline & Coefficient & Std Error & t-ratio & p-value & \\
\hline Const & 0.0260383 & 0.0504058 & 0.5166 & 0.61018 & \\
\hline$\Delta$ LCrdpgdp $\mathrm{p}^{\text {manf }}$ & -0.0639774 & 0.131475 & -0.4866 & 0.63095 & \\
\hline$\Delta L C_{\text {rdpgdp }}{ }^{\operatorname{manf}} t_{t-2}$ & 0.0658493 & 0.100225 & 0.6570 & 0.51742 & \\
\hline$\Delta$ LCrdpgdp ${ }^{\operatorname{manf}} t_{t-3}$ & 0.0504633 & 0.0658303 & 0.7666 & 0.45081 & \\
\hline$\Delta \mathrm{Irgdpt}$ & 0.398621 & 0.118003 & 3.3781 & 0.00249 & \\
\hline$\Delta \operatorname{Lrgdp_{t-1}}$ & 0.0715002 & 0.13891 & 0.5147 & 0.61146 & \\
\hline$\Delta \operatorname{Lrgdp}_{t-2}$ & -0.0669595 & 0.137797 & -0.4859 & 0.63142 & \\
\hline$\Delta \mathrm{I}$ Saygdpt. & 0.327509 & 0.226868 & 1.4436 & 0.16178 & \\
\hline$\Delta R D T R_{-1}$ & -0.00159359 & 0.00281963 & -0.5652 & 0.57720 & \\
\hline$\Delta$ Finib $_{4}$ & -0.108353 & 0.0507604 & -2.1346 & 0.04321 & $* *$ \\
\hline$\Delta$ Finlb $_{t-1}$ & -0.00371593 & 0.0542616 & -0.0685 & 0.94597 & \\
\hline $\mathrm{ECM}_{t-1}$ & -0.765612 & 0.163249 & -4.6898 & 0.00009 & \\
\hline R-squared & 0.869671 & \multicolumn{2}{|c|}{ Adjusted R-squared } & \multicolumn{2}{|c|}{0.809937} \\
\hline Schwarz c1 & 24.41014 & \multicolumn{2}{|l|}{ Durbin's h } & \multicolumn{2}{|c|}{12.04020} \\
\hline
\end{tabular}

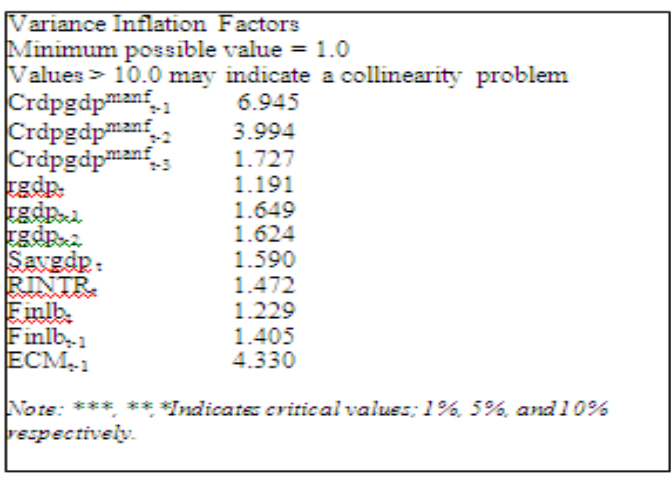

The Short Run Dynamics of the ARDL shows that the lagged error correction term $\left(\mathrm{ECM}_{\mathrm{t}-1}\right)$ is negative and highly significant at 1 percent. Its coefficient -0.765612 implies a high fairly slow speed of adjustment to equilibrium after a shock. Approximately $76.6 \%$ of disequilibria from previous period shocks are adjusted into long run equilibrium in the current period. The significant negative coefficient of the $\mathrm{ECM}_{\mathrm{t}-1, \mathrm{t}}$ further buttress the existence of long run relationship among the variables. Interestingly, the result of the short run approximately conforms perfectly to that of the long run ( $\operatorname{Lrgdp} \approx 0.4$, and finlb $\approx-0.1)$, even when dynamism is incorporated. Like in the long run, credit crunch phenomenon is still obtainable as regards to the credit to the manufacturing against increasing deposit liabilities. Financial liberalization, both current and 
immediate past did not have a positive effect on the credit to this real sector of manufacturing, significant at 5 percent, the degree of liberalization in the financial system had an adverse effect on the credit to the manufacturing sector.

The reliability and explanatory power of the short-run dynamic estimate is depict by its goodness of fit $\mathrm{R}^{2}$ at $86.97 \%$, further supported by a high adjusted $\mathrm{R}^{2}$ of 0.809937 . This implies that the explanatory variables in the short-run model account for approximately $87 \%$ variation in the change of the dependent variable, while the remaining $13 \%$ is accounted by variables not explicitly included in the model but comprised in the random or error term.

According to Pesaran and Shin (1999), the stability of the estimated coefficient of the error correction model should also be geographically investigated. A graphical representation of the Cummulative Sum (CUSUM) and the Cummulative Sum of Square (CUSUMSQ) of the Recursive Residual is shown below to indicate stability in the coefficient over the sample periods, despite the threat in the CUSUMSQ as stability trod on the lower border.

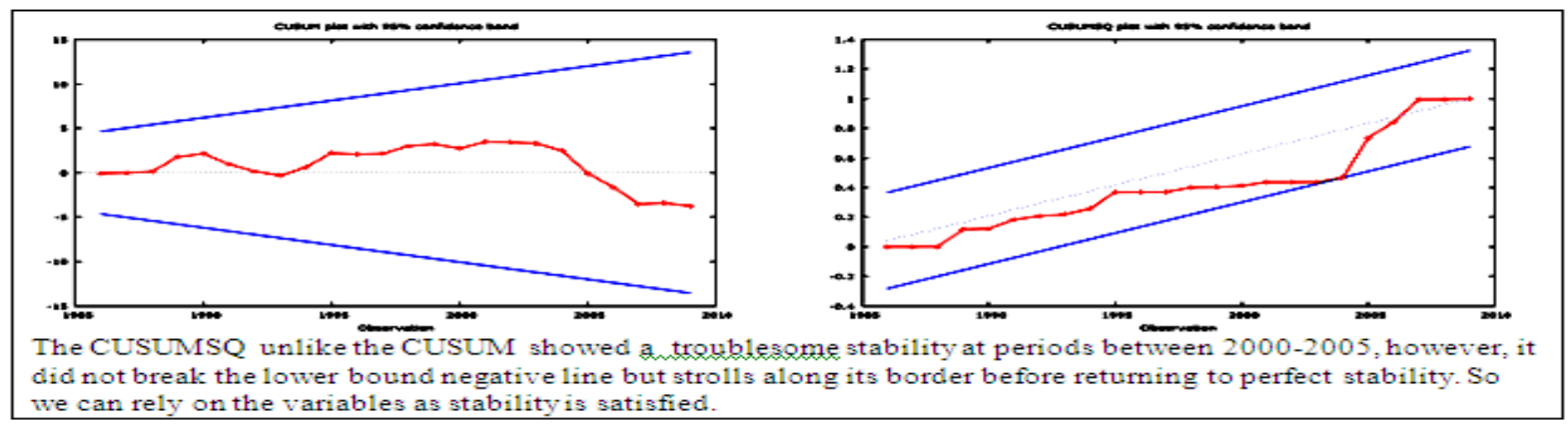

Equation Four: CREDIT TO SMEs

On the credit to the Small and Medium Enterprises, the ARDL estimation for equation four, has a calculated F-statistics as $\mathrm{F}_{\text {Crdgdp }}{ }_{\text {SMEs }}$ (LCrdgdp ${ }^{\text {SMEs }} \mid$ LSavgdp, Lrgdp, RINTR, FinLB) $\approx 6.20$ for ARDL $(3,1,0$, $0,1)$ is far higher than the upper bound critical Value 5.06 at $1 \%$ significance level (Peseran et al, 2001: see Appendix for extract), Thus suggesting the possible existence of a co-integrating long-run relationship among the variables the model.

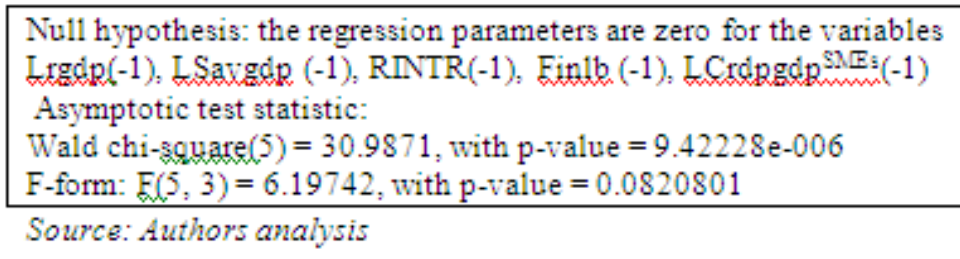

To the long and short run coefficients estimation.

\section{Long Run:}

Model 4:OLS, using observations 1992-2009 $(\mathrm{T}=18)$

Dependent variable: LCrdpgdp ${ }^{\text {SMEs }}$

\begin{tabular}{|l|c|c|c|c|c|}
\hline & Coefficient & Std. Error & t-ratio & p-value & \\
\hline Const & 36.9981 & 4.9627 & 7.4552 & $<0.00001$ & $* * *$ \\
\hline Lrgdp & -2.67889 & 0.440381 & -6.0831 & 0.00004 & $* * *$ \\
\hline LSaygdp & -0.284336 & 0.356415 & -0.7978 & 0.43934 & \\
\hline RINTR & -0.00355898 & 0.00821744 & -0.4331 & 0.67204 & \\
\hline FinLR. & -0.406256 & 0.265682 & -1.5291 & 0.15020 & \\
\hline
\end{tabular}

Variance Inflation Factors

Minimum possible value $=1.0$

Values $>10.0$ may indicate a

collinearity problem

Irgdp $\quad 1.989$

ISaygdp $\quad 1.525$

RINTR $\quad 1.236$

Fiblb $\quad 1.749$

\begin{tabular}{|l|c||l|l|}
\hline R-squared & 0.898185 & Adjusted R-squared & 0.866857 \\
\hline Schwarz criterion & 31.26380 & Durbin-Watson & 1.357474 \\
\hline
\end{tabular}

Note: $* * *, * * *$ Indicates critical values; $1 \%, 5 \%$, and $10 \%$ respectively.

Before going into the analysis of the result on SMEs, we observe the problem posed by the too short a period for regression (18 years), whereas, for reliability and the essence of forecasting, data should be at least 30 years for a small sample size, but in this case, we are fixed with a one way choice given that data available on SMEs were only available from 1992 onwards causing a problem of asymptotic information. However, going by the rule of thumb that spuriousity is first observed were the Durbin-Watson value exceeds the R-Squared. In this case the DW has a higher value. The long run results on the growth rate of Credit Loan and advances to the 
Small and Medium Enterprises as a ratio of the Gross Domestic Product (LCrdpgdp ${ }^{\text {SMES }}$ ), shows that only the growth in real gross domestic product had a significant value at 1 percent which was negative -2.67889; a unit increase in economic growth ceteris paribus, induces a fall in the average growth in credit to the SMEs by $2.68 \%$ in the steady long run suggesting a total neglect of the SMEs. Neither the real interest rate, total financial domestic savings composed majorly of the total deposit liability in the commercial Deposit Money Banks (DMBs) nor liberalizing the financial system, exert any significant effect on the growth of credit to the SMEs. Therefore, we confidently conclude that credit crunch was paramount in the unit. The goodness of fit despite the short period was okay at 89 percent.

ARDL (3, 1, 0, 0, 1) Model ECM-Short Run Result for Model 4.

Model 4: OLS, using observations 1996-2009 $(\mathrm{T}=14)$

Dependent variable: $\Delta \mathrm{L}$ Crdpgdp ${ }_{\mathrm{t}-1} \mathrm{SME}$

\begin{tabular}{|c|c|c|c|c|c|}
\hline & Coefficient & Std. Error & t-ratio & p-value & \multirow{3}{*}{$\begin{array}{l}\text { Variance Inflation Factors } \\
\text { Minimum possible value }=1.0 \\
\text { Values }>10.0 \text { may indicate a } \\
\text { collinearity problem }\end{array}$} \\
\hline Const & -1.10321 & 0.382802 & -2.8819 & \begin{tabular}{l|l}
0.06343 & $*$
\end{tabular} & \\
\hline$\Delta \mathrm{L}$ Crdpgdpt ${ }_{t-1}^{\mathrm{SNE}}$ & 1.54425 & 0.827486 & 1.8662 & 0.15885 & \\
\hline$\Delta \mathrm{L}$ rdpgdp $\mathrm{t}-2 \mathrm{SME}$ & 2.09463 & 1.05471 & 1.9860 & 0.14123 & $\operatorname{rgdp} \quad 1.191$ \\
\hline$\Delta \mathrm{L} \mathrm{Crdpgdn,t-3} \mathrm{SNE}$ & 0.566683 & 0.422177 & 1.3423 & 0.27204 & rgdp $\cdots 2$ \\
\hline$\Delta \mathrm{Lrgclp}$ & 9.25515 & 5.87455 & 1.5755 & 0.21323 & $\begin{array}{l}1.624 \\
1.590\end{array}$ \\
\hline 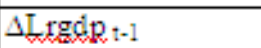 & 7.32432 & 5.31821 & 1.3772 & 0.26221 & RINTR: \\
\hline$\Delta$ ISaxgdp t & 3.99024 & 2.30671 & 1.7298 & 0.18210 & Finlb: \\
\hline$\Delta \mathrm{RNDT}_{\mathrm{t}}$ & -0.0147645 & 0.0116633 & -1.2659 & 0.29492 & Finlb:-1 \\
\hline$\Delta$ Finf $B$ & 1.34402 & 1.05825 & 1.2700 & 0.29363 & Crdpgdp $* 1$ \\
\hline$\Delta$ FinI B,$t-1$ & 1.34915 & 0.631637 & 2.1360 & 0.12232 & Crdpgdp $\div 2$ \\
\hline $\mathrm{ECM}_{\mathrm{t}-1}$ & -1.49713 & 0.670381 & -2.2333 & 0.11166 & Crdpgdp $: 3$ \\
\hline R-squared & 0.898617 & Adjusted R-sc & ared & 0.560672 & $\begin{array}{l}\text { Note: } * * * * * * \text { Indicate critical values; } \\
1 \%, 5 \% \text { and } 10 \% \text { respectively. }\end{array}$ \\
\hline Schwarz criterion & 14.39691 & Durbin-Watso & & 1.962152 & \\
\hline
\end{tabular}

Against the F-statics, the Short Run Dynamics of the ARDL shows that the lagged error correction term $\left(\mathrm{ECM}_{\mathrm{t}}\right.$ ${ }_{1}$ ) is negative but not significant implying that no long run relationships exist among the variables. This can be due to the fact that the estimation period before and even after lags have been imposed is relatively too short ( $\mathrm{T}=$ 14) for proper information to be deduced. Given the short duration, as expected the Durbin Watson value is satisfied at 1.96, greater than the R-squared that fits well at approximately 89.9 percent, the regression is not spurious and thus reliable for analysis. Back to the result, we note that in the short run both past and present estimated coefficients of the regressors were all insignificant. Suggesting a similar case of neglect and credit shortage to the Small and Medium Scale enterprises given the short sample period. The graphical representation of the Cummulative Sum (CUSUM) and the Cummulative Sum of Square (CUSUMSQ) of the Recursive Residual for model four is shown below to indicate a linear stability in the coefficient over the sample periods, this is on account of the short sample period (which was far below 30 years):

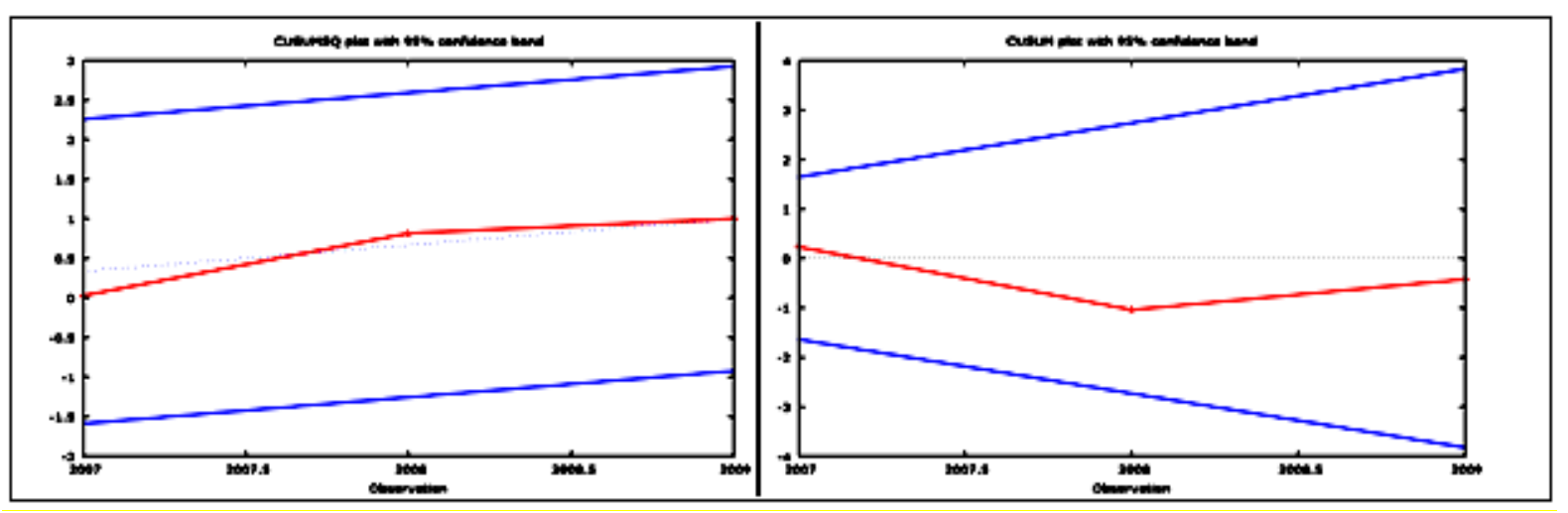

VI. Conclusion And Recommendation

The aim of the study was to ascertain the effect of deregulating the Nigerian financial system on the key credit component in the private sector economy of the nation, following the tenet as put forward by 
Mckinnon and Shaw (1973) in the Complimentary Hypothesis, that a repressed financial sector hinders output growth. Thus financial liberalization theory argues for improved growth through financial deepening which implies not only higher productivity of capital but also higher savings which leads to higher volume of investment credit. To reap this benefit, Nigeria amongst many developing countries where credit is constrained has adopted a variety of liberalizing reforms in her financial system since 1986. Following this changes, the World Bank News Report (2010) claims that credit crunch does not exist in Nigeria and the urgent need to revamping the non-oil sector. Questioning the absence of credit crunch in the presence of high unemployment, poor economic development and the uneven income in the country, causes us to investigate on the key credit units \{credits to the real sector (Agriculture, Manufacturing, and SMEs), to know if indeed financial liberalization has been of benefit and whether or not credit crunch exist when credit components are considered individually. Employing data from 1970 to 2009, sourced from the Central Bank of Nigerian Statistical Bulletins, on an Autoregressive Distributed Lag (ARDL) Model to test for the long and short run impact of financial liberalization and the presence of credit crunch on the credits in the private economy, our results interestingly reveals that liberalizing the Nigerian financial system had an adverse boomerang effect on the credits allocated to the real sectors in the long run and in the short run, financial liberalization was in all insignificant and negative.

On investigating the presence of credit crunch in the long and short run, our results leads us to the conclusion that Deposit Money Banks (DMBs) in Nigeria have a strong discriminating credit behaviour towards the real sectors (Agriculture, Manufacturing and the SMEs), as credit crunch is present in these sectors in both the short and long run indicative by the inverse relationship between increasing deposit liabilities that make up savings and the credit that flows to these sectors. Thus we conclude that the DMBs in Nigeria are not only risk averse towards long term investment credit to the vital sectors such as the real sectors (agriculture and manufacturing) and SMEs that bring about visible development and growth in the economy, but also lack the capacity in terms of technicality to arrest the issue of adverse selection and moral hazard posed by high asymmetric information in an uncertain economic environment leading to high cases of non-performing loans in non-real sector units or probably lack strong capital base (despite recapitalization and consolidation) to support real investment credit.

Given result of the study, we recommend increased prudential regulations and strict supervision that entails credit guidelines to induce higher credit to the real sector against liberalization, and also having the government bank (CBN) extending its operation to commercial bank level (even if with a different name and/or board) to induce competition at commercial banking levels. Furthermore, in as much as money (availability of credit) may answer all things, the degree of its potency to induce significant positive multiplier effect is dependent on wisdom applied in pattern and areas of investment. Having established the fact that Nigeria has all the resources required to be a first class nation (on the assumption of good leadership/governance), a change need be done in the pattern of sectorial investment; agricultural credit financing need to channelled to improving the storage and processing of the yields to bi-produce domestically (input and expand on the value chain of agric-produce), embargo need be put on imported agric produce, government budget and monitoring should be redirect to infrastructural development (i.e. power, road network, irrigation, build local refineries, and water). The government need to wake up, and become pro-active in response to domestic threats and terrorism, with no top or low sacred-dog spared; for all effort to save homeland will be a waist if security and justice is far off.

\section{References}

[1] Adegeye, A.I. and J.S. Ditto, (1985): Essential of Agricultural Economies. New Edn., Impact Publishers, Ibadan, Nigeria.

[2] Avinash .R and Tanisha .M. Ryan (2010): "An Assessment Of The Impact Of The Sectoral Distribution Of Commercial Bank Credit On Economic Growth And Development In Trinidad And Tobago". CBB Working Paper (2010) Central Bank of Barbados

[3] Bandiera .O, Caprio .G, Honohan .P, and Schiantarelli .F (2002): "Does Financial Reform Raise or Reduce Savings"? Review of Economics and Statistics, May 82 (2): Pp. $239-263$.

[4] Bekaert G, Harvey, C.R, Lundblad, C (2004): “Does Financial Liberalization Spur Growth?” NBER Working Paper, No 7763, Cambridge, MA: National Bureau of Economic Research.Benson O. (2012): "Institutions, Macroeconomic Policy and the Growth of the Agricultural Sector in Nigeria." Global journal of Human Social Sciences. Volume 12, Issue 1 Version 1.0 January 2012. Pp 1-8 Central Bank of Nigeria (CBN) Annual Report for 2011Corporate Nigeria (2010/2011): Corporate Nigeria - The Business, Trade and Investment Guard 2010/2011. www.corporate-nigeria.com/ Efobi, U. R. and Osabuohien, E.S. (2011): "Assessment of the Role of Agricultural Credit Guarantee Scheme Fund in Promoting Non-Oil Export in Nigeria”, Current Research Journal of Economic Theory. Vol. 3 No. 1, pp. 20-28

[5] Eichengreen, B and Leblang, D. (2003): "Capital Account Liberalization and Growth: Was Mr Matahthir Right?" International Journal of Finance and Economics, volume 8. Pp 205-224.

[6] Emeni F.K. and Okafor C. (2008): Effects of bank mergers and acquisitions on small business lending in Nigeria", African Journal of Business Management, Volume 2 (9), Pp 146-156, September 2008

[7] Emenuga, C. (2009): "The Outcome of Financial Sector Reforms in West Africa": Chapter 14. AFRICAN VOICES ON STRUCTURAL ADJUSTMENT. International Development Research Centre. Pp 1-24. Emenuga, C. (1996): "Institutional Setting For Post Reform Management of the Nigerian Financial System: A Case For Central Bank Independence.” Post-Reform Management of the Nigerian Economy, Nigerian Economic Society, Published 1996 Annual Conference Proceedings, 1996b.

[8] Emmanuel A. O (2006): "Financial Liberalization and Savings Mobilization in Nigeria". CBN Bullion. Volume 30. No.1. Pp. 5262. Ewegbemi .D (2007): Nigeria's Dependence on Oil; A Curse on Economic Nationalism. Reforming the Nearly Unreformable. 
The Economist Magazine, August $7^{\text {th }}-13^{\text {th }} 2007$. Accessible at: www.dawodu.com/ewegbemi1.htm FAO- Food and Agricultural Organisation (2011): Online: http://faostat.fao.org/home

[9] Fowowe Babajide (2008): "Financial Liberalization Policies and Economic Growth: Panel Data Evidence from Sub-Saharan Africa". African Development Review, volume 20, issue. Pp 549-574.

[10] Fry, M.J (1978): "Money and Capital or Financial Deepening in Economic Development", Journal of Money, Credit and Banking, Vol 10, November. Pp 464- 475.

[11] Fry, M.J (1995): Money, Interest Rate and Banking in Economic Development, Second Edition Baltimore: john Hopkins University Press.

[12] Gibson, H. and Tsakalotos, E. (1994): "The Scope and Limits of Financial Liberalization in Developing Countries: A Critical Survey.” The Journal of Development Studies. 30,3 (April), 1994: Pp 578-628.

[13] Henny Medyawati, Muhammad Yunanto, and Gunadarma University (2011): "Banking Development, Agriculture and Manufacturing Industry Sector in Economic Growth in Indonesia: Do They Influence?". International Journal of Trade, Economics and Finance, Vol. 2, No. 4, August 2011. Pp 312-317.

[14] Levine, R. (2001): “International Financial Liberalization and Economic Growth". Review of International Economics, (109): Pp 83-109.

[15] Loayza .N, Schmidt-Hebbel .K, Serven .L (2000): "What Drives Private Savings Across the World"? Review of Economics and Statistics, May 2000; Volume 82(2): Pp 165 - 181.

[16] Mckinnon, R.I (1973): Money and Capital in Economic Development. Washington, D.C. Brookings Institute.

[17] Mishkin, F. (2001): "Finance Policies and the Prevention of financial Crises in Emerging Market Countries". NBER Working Paper No. 8087

[18] Muhsin K. and Eric J. P (2001): “A System Test of McKinnon's Complementarity Hypothesis with an Application to Turkey”. \{Online\}: www.ecoturk.org/muhsin.pdf

[19] NIPC (2002): Nigerian Investment Promotion Commission- official website: nipc.gov.ng/polpropage.htm

[20] Ogwuma, P.A (1993): "Recent Developments in the Nigerian Financial Services Industry: Problems and Challenges". An Address at Annual dinner of the Chartered Institute of Bankers of Nigeria, Lagos, November.

[21] Ogujiuba, K., F. Ohuche, A. Adenuga (2004):. Credit Availability to Small and Medium Scale Enterprises in Nigeria: Importance of New Capital Base for Banks-Background and Issues // AIAE Working Paper, 2004.

[22] Ojo, M.O (1993): A Review and Appraisal of the Nigerian Experience with Financial Sector Reform. Occasional Paper 8 (CBN), August

[23] Okpara G.C (2010): "The Effect of Financial Liberalization on Selected Macroeconomic Variables: Lesson from Nigeria. The International Journal of Applied Economics and Finance. Volume 4. No.2. Pp 53-61, 2010.

[24] Rahila M, Rehmat U.A and Zakir H. (2010): "Investment, Savings, Interest Rate and Bank Credit to Private Sector Nexus in Pakistan". International Journal of Marketing Studies. Volume 2, No. 1; May 2010. Pp 140-146

[25] Rehmat U.A, Rahila M, Zakir H, Falak S. (2010): "Rate of Interest, Financial Liberalization and Domestic Savings Behaviour in Pakistan”. International Journal of Economics and Finance. Volume 2. No. 4 (November 2010). Pp 75-81

[26] Reinhart, Carmen, Tokatlids and Ioannis, (2005): "Before and After Financial Liberalization". Munich Personal RePEc Archive. Online at: http://mpra.ub.uni-muenchen.de/6986/

[27] Shahnoushi .N, Ebadi .A.G, Daneshvar .M, Shokri .E and Motallebi .M (2008): "Causality Between Financial Development and Economic Growth in Iran”. World Applied Science Journal. Volume 4. No.5. Pp 736-740.

[28] Shaw, E.S. (1973): Financial Deepening in Economic Development, Oxford University Press, New York.

[29] Stulz, R.M (1999): "Globalization, Corporate Finance, and Cost of Capital". Journal of Applied Corporate Finance, Vol. 12, Issue 3. Pp 8-25, fall 1999.

[30] Udechukwu .F.N (2003): Survey of small and medium scale industries and their potentials in Nigeria. Paper presentation at SEMINAR ON SMAL AND MEDIUM INDUSTRIES EQUITY INVESTMENTS SCHEME (SMIEIS), organised by Central Bank of Nigeria (CBN).CBN Training Centre, Lagos. Accessed in 2012 from http://www.cenbank.org/documents/publications.asp.

[31] UNIDO, CBN, BOI (2010); Unleashing Agricultural Development in Nigeria through Value Chain Financing. Working Paper. November 2010. United Nations Industrial Development (UNIDO). Vienna, Australia.

[32] Toby A. (2011): "Modelling Bank Management, Rural Lending and Small Business Finance in Nigeria". Global Journal of Management and Business Research, Volume 11. Issue 7 Version 1.0, July 2011. Pp 31-46

[33] Woldie .A and Kolawoleadeniji .A (2008): "How has Financial Liberalization Improved the Flow of External Finance for SMEs in Nigeria". Banks and Banking Systems. Volume 3. Issue 3, 2008. Pp 20-30.

[34] World Bank News Report (2010): "World Bank Commends CBN: "Say No Credit Crunch in Nigeria"; by Economic Confidential. September (2010). www.economicconfidential.com/x/index.php/national-news/413-world-bank-commends-cbn-credit-crunch-innigeria

\section{APPENDIX}

Extracted from Pesaran et al (2010), Case III: Unrestricted Intercept, With No Trend

\begin{tabular}{|c|c|c|c|c|c|c|c|c|}
\hline & \multicolumn{2}{|c|}{$0.100(\mathbf{1 0})$} & \multicolumn{2}{|c|}{$0.050(\mathbf{5} \%)$} & \multicolumn{2}{c|}{$\mathbf{0 . 0 2 5}(\mathbf{2 . 5} \%)$} & \multicolumn{2}{c|}{$0.010(\mathbf{1})$} \\
\hline $\mathrm{K}$ & $\mathrm{I}(\mathbf{0})$ & $\mathrm{I}(\mathbf{1})$ & $\mathrm{I}(\mathbf{0})$ & $\mathrm{I}(\mathbf{1})$ & $\mathrm{I}(\mathbf{0})$ & $\mathrm{I}(\mathbf{1})$ & $\mathrm{I}(\mathbf{0})$ & $\mathrm{I}(\mathbf{1})$ \\
\hline 0 & 6.58 & 6.58 & 8.21 & 8.21 & 9.80 & 9.80 & 11.79 & 11.79 \\
\hline 1 & 4.04 & 4.78 & 4.94 & 5.73 & 5.77 & 6.68 & 6.84 & 7.84 \\
\hline 2 & 3.17 & 4.14 & 3.79 & 4.83 & 4.41 & 5.52 & 5.15 & 6.36 \\
\hline 3 & 2.72 & 3.77 & 3.23 & 4.35 & 3.69 & 4.89 & 4.29 & 5.61 \\
\hline 4 & 2.45 & 3.52 & 2.86 & 4.01 & 3.25 & 4.49 & 3.74 & 5.06 \\
\hline 5 & 2.26 & 3.35 & 2.62 & 3.79 & 2.96 & 4.18 & 3.41 & 4.68 \\
\hline 6 & 2.12 & 3.23 & 2.45 & 3.61 & 2.75 & 3.99 & 3.51 & 4.43 \\
\hline
\end{tabular}

Notes: Asymptotic critical value bounds are obtained from Table CI (iii) case III: unrestricted intercept and no trend for $\mathrm{k}=4$ (Pesaran et al, 2001). 
Financial Liberalization Index: Liberalization Variables and Years

\begin{tabular}{|c|c|c|c|c|c|c|c|c|}
\hline Year & $\begin{array}{l}\text { BPD } \\
\mathrm{R}\end{array}$ & IRL & $\begin{array}{l}\text { PRI } \\
\text { DC }\end{array}$ & $\begin{array}{l}\text { DSC } \\
\text { A }\end{array}$ & $\begin{array}{l}\text { FEB- } \\
\text { DBL }\end{array}$ & $\begin{array}{l}\text { EXCL- } \\
\text { DFEM }\end{array}$ & $\begin{array}{l}\text { CAPM } \\
\text { L-EDH }\end{array}$ & $\begin{array}{l}\text { DEGREE OF } \\
\text { LIBERALIZATION }\end{array}$ \\
\hline 1970 & 0 & 0 & 0 & 0 & 0 & 0 & 0 & 0 \\
\hline 1971 & 0 & 0 & 0 & 0 & 0 & 0 & 0 & $\mathbf{0}$ \\
\hline 1972 & 0 & 0 & 0 & 0 & 0 & 0 & 0 & $\mathbf{0}$ \\
\hline 1973 & 0 & 0 & 0 & 0 & 0 & 0 & 0 & $\mathbf{0}$ \\
\hline 1974 & 0 & 0 & 0 & 0 & 0 & 0 & 0 & $\mathbf{0}$ \\
\hline 1975 & 0 & 0 & 0 & 0 & 0 & 0 & 0 & $\mathbf{0}$ \\
\hline 1976 & 0 & 0 & 0 & 0 & 0 & 0 & 0 & $\mathbf{0}$ \\
\hline 1977 & 0 & 0 & 0 & 0 & 0 & 0 & 0 & $\mathbf{0}$ \\
\hline 1978 & 0 & 0 & 0 & 0 & 0 & 0 & 0 & $\mathbf{0}$ \\
\hline 1979 & 0 & 0 & 0 & 0 & 0 & 0 & 0 & $\mathbf{0}$ \\
\hline 1980 & 0 & 0 & 0 & 0 & 0 & 0 & 0 & $\mathbf{0}$ \\
\hline 1981 & 0 & 0 & 0 & 0 & 0 & 0 & 0 & $\mathbf{0}$ \\
\hline 1982 & 0 & 0 & 0 & 0 & 0 & 0 & 0 & $\mathbf{0}$ \\
\hline 1983 & 0 & 0 & 0 & 0 & 0 & 0 & 0 & $\mathbf{0}$ \\
\hline 1984 & 0 & 0 & 0 & 0 & 0 & 0 & 0 & $\mathbf{0}$ \\
\hline 1985 & 0 & 0 & 0 & 0 & 0 & 0 & 0 & $\mathbf{0}$ \\
\hline 1986 & 0 & 0 & 0 & 0 & 0 & 1 & 0 & 1 \\
\hline 1987* & $\mathbf{0}$ & 1 & $\mathbf{0}$ & $\mathbf{0}$ & 1 & 1 & $\mathbf{0}$ & 3 \\
\hline 1988 & 0 & 1 & 0 & 0 & 1 & 1 & 0 & 3 \\
\hline 1989 & 0 & 1 & 0 & 0 & 1 & 1 & 0 & 3 \\
\hline 1990 & 1 & 1 & 0 & 0 & 1 & 1 & 0 & 4 \\
\hline 1991 & 1 & 0 & 0 & 0 & 0 & 1 & 0 & 2 \\
\hline 1992 & 1 & 1 & 0 & 1 & 0 & 1 & 1 & 5 \\
\hline 1993 & 1 & 1 & 1 & 1 & 0 & 1 & 1 & 6 \\
\hline 1994 & 1 & 0 & 1 & 1 & 0 & 0 & 1 & 4 \\
\hline 1995 & 1 & 0 & 1 & 1 & 0 & 1 & 1 & 5 \\
\hline 1996 & 1 & 0 & 1 & 1 & 0 & 1 & 1 & 5 \\
\hline 1997 & 1 & 0 & 1 & 1 & 0 & 1 & 1 & 5 \\
\hline 1998 & 1 & 0 & 1 & 1 & 0 & 1 & 1 & 5 \\
\hline 1999 & 1 & 0 & 1 & 1 & 0 & 1 & 1 & 5 \\
\hline 2000 & 1 & 0 & 1 & 1 & 0 & 1 & 1 & 5 \\
\hline 2001 & 1 & 0 & 1 & 1 & 0 & 1 & 1 & 5 \\
\hline 2002 & 1 & 0 & 1 & 1 & 0 & 1 & 1 & 5 \\
\hline 2003 & 1 & 0 & 1 & 1 & 0 & 1 & 1 & 5 \\
\hline 2004 & 1 & 0 & 1 & 1 & 0 & 1 & 1 & 5 \\
\hline 2005 & 1 & 0 & 1 & 1 & 0 & 1 & 1 & 5 \\
\hline 2006 & 1 & 1 & 1 & 1 & 0 & 1 & 1 & 6 \\
\hline 2007 & 1 & 1 & 1 & 1 & 0 & 1 & 1 & 6 \\
\hline 2008 & 1 & 1 & 1 & 1 & 0 & 1 & 1 & 6 \\
\hline 2009 & 1 & 1 & 1 & 1 & 0 & 1 & 1 & 6 \\
\hline
\end{tabular}

Note:

The table shows a summary of financial liberalization policy index derived using principal component analysis. Each cell gives the presence or absence of liberalization in that variable. 0 indicating no liberalization and 1 indicating liberalization. The last column is the summation of the total presence of liberalization among the seven variables; the study uses this as a proxy to measure the degree of financial liberalization.

$\mathbf{B P D R}=$ Bank Privatization/Denationalization and Restructuring. IRL= Interest Rate Liberalization/Deregulation. PRIDC= Prudential Regulation and Introduction of Indirect Policy Controls. DSCA = Direct/Selective Credit Abolition. FEB-DBL= Free Entry into Bank-Deregulation of Bank Licensing. EXCL-DFEM= Exchange Rate Liberalization-Deregulation of Foreign Exchange Market (introduction of autonomous exchange market and bureaux de change). CAPML-EDH= Capital Market LiberalizationEstablishment of Discount Houses. 